\title{
A short history of the form of octagonal and elliptical city squares
}

\author{
Maciej Motak \\ mmotak@pk.edu.pl | (D) https://orcid.org/000-0002-5223-9895 \\ Magdalena Woźniczka \\ mmwozniczka@interia.pl | (iD https://orcid.org/0000-0002-4787-9978 \\ Chair of History of Architecture and Monument Preservation, Faculty \\ of Architecture, Cracow University of Technology
}

Scientific Editor: Mateusz Gyurkovich, Cracow University of Technology

Technical Editor: Matgorzata Sikora, Cracow University of Technology Press

Language Verification: Timothy Churcher Merlin Language Services

Typesetting: Anna Basista, Cracow

University of Technology Press

Received: June 1, 2021

Accepted: September 23, 2021

Copyright: @ 2021 Motak, Woźniczka. This is an open access article distributed under the terms of the Creative Commons Attribution License, which permits unrestricted use, distribution, and reproduction in any medium, provided the original author and source are credited.

Data Availability Statement: All relevant data are within the paper and its Supporting Information files.

Competing interests: The authors have declared that no competing interests exist.

\begin{abstract}
The article starts with the short discussion of two geometrical figures, i.e., octagon and ellipse, their genesis in architecture and urban design, and the examples of buildings whose plans were based upon them. Then, the selected octagonal and elliptical city squares are discussed: their genesis, context, layout, architecture surrounding the square, objects appearing in the square and, most specially, urban form and composition. The theory of architectural-landscape interiors has been applied to pinpoint the type of city squares by the assessing of the degree of openings in the square's perimeter. The review consists of 22 case studies ( 9 octagonal and 13 elliptical) from the $15^{\text {th }}$ to the $20^{\text {th }}$ century. The last discussed case in each group, both atypical created in Krakow in the $20^{\text {th }}$ century, are discussed even more thoroughly. The conclusions were presented first separately for octagonal and elliptical city squares and finally also for both groups in a comparative way.
\end{abstract}

Keywords: ellipse, octagon, urban form, Kurdwanów, osiedle Urzędnicze 


\section{Introduction}

The article's title, especially the word 'short', has two aspects. The history of the city squares, the shapes of which are stated in the title, is not long if compared both to the history of the city square and history of the city. The first cities emerged many thousands of years ago, whereas the first city squares that were close to the present idea of the city square were created around the sixth or fifth century BC in the culture of Ancient Greece. The city squares of the discussed shapes appeared only in the modern era: octagonal city squares since the time of the Renaissance (theoretical proposals in the fifteenth and sixteenth centuries, and the projects built since the seventeenth century); elliptical city squares since the Baroque era (seventeenth and eighteenth centuries, though more numerously only since the nineteenth century). The article itself is also relatively short since it contains an introductory analysis of the problem with selected cases representing urban forms of city squares with octagonal or elliptical plans.

Both figures - ellipse and octagon - are regarded as special, attributed with an outstanding form of a certain degree of sophistication. Their position seems to be in between the basic and most perfect figures (circle and square, respectively) and the figures (or their variations or compilations) of especially complicated shapes. Both figures are still used in the design of public space, although not very often. Actually, they never dominated the design of public space, even when they were quite popular. The most numerous groups in the entire history of urban design have been by far comprised of city squares of rectangular plans (including square plans) and by the city squares and other spaces of irregular plans.

The research was mostly based upon the studies of literature, case studies, graphic analysis and comparative analysis. Additionally, in two cases that are discussed as the last of their respective groups, the authors benefitted from the results of their detailed research (including the search in the archives) concerning selected areas of Krakow that had not been researched before. The two solutions of city space, inspired by octagons or ellipses, which appeared in those areas in the twentieth century are regarded by the authors as being quite exceptional. Moreover, the research was referred to the theory of landscape interiors by Janusz Bogdanowski, which deals extensively with composition and planning in landscape architecture. The typology of architectural-landscape interiors is a relatively small part of his theory (Bogdanowski, 1976: 62-63, 88-89). However, due to its focus on the typology of landscapes, one can find it quite appropriate for considering city squares and other urban spaces. According to Bogdanowski's theory, the character of the city interior (wnętrza, perceived as space) is defined by the filling of 'walls' and the leaving of 'openings', which may take place in a conscious or more natural way. Depending on the amount of openings in the 'walls', the interiors can be of three different types (Bogdanowski, 1976: 89)1 ${ }^{1}$. The first is the 'concrete' type, with a closed interior (wnettrze konkretne) with openings up to $30 \%$ of the total perimeter. The second is the 'objective' type, which has a semi-closed interior (wnętrze obiektywne) with openings ranging from 30 to $60 \%$ of the total perimeter. The third one is the 'subjective' type with a semi-open interior (wnętrze subiektywne) with openings exceeding $60 \%$ of the total perimeter. Aside from the quality of the 'walls' (ściany) of the interiors themselves may also influence the final impression of the entire interior. A full compactness of the built-up street frontage results in a closed interior, while the porosity of greenery results rather in the semi-closed interior and the distant enclosure in the semi-open interior.

Some of the city squares that are presented in the article have already been discussed with regard to their origin as well as their historic and contemporary form; the appropriate literature is quoted. Urban literature on the city squares

1 The Polish terms were quoted from the book. The English names were translated by the authors. 
is available (Zucker, 1959; Webb, 1990), as is mathematical literature on the geometrical figures (Mezer, 2010). One may add that the literature on architecture and urban design has paid more attention to other geometrical shapes - especially the circle (Johnston, 1983; van Ruler, 1984: 22-25; Radwański, 2018) and the square (Grimal, 1954; Munari, 1960 [reprint Maurizio Corraini, Mantova 2011]) than to the ellipse and the octagon.

\section{Octagons and ellipses in the history of architecture - an outline}

The ability to draw both figures undoubtedly dates back to the dawn of human civilisation. It was already mastered in the ancient times, both Greek (Hellenistic period) and Roman. Moreover, the particular values of the figures were already appreciated, which is confirmed by the well-preserved buildings with either octagonal or elliptical plans as well as by the theoretical considerations.

A unique scheme repeated after Vitruvius, one of many drawings that were part of his Ten Books, confirms an interest in the octagon. It has been preserved in the manuscript of the Harleian Codex from the first quarter of the ninth century, the oldest copy of the Ten Books. It shows an octagonal scheme of winds (so-called wind rose) in accordance with the description in Book I, Chapter 6; therefore, its genesis dates back to the end of the first century BC (Witruwiusz, 1999: 263) .

The octagonal plan became the base of the horologion - a meteorological tower (so-called tower of winds) in Athens; this was a building combining the functions of a water clock, a sundial and a weather vane. The building, which is attributed to Andronicus Cyrrhus, dates back to the late second or early first century BC. Its plan's medium diagonal - the span - is 7.5 metres and the height is over $12 \mathrm{~m}$. In the late Roman period, the octagonal mausoleum in the Emperor Diocletian Palace ensemble in Split (c. 300) and the Nativity Basilica's octagonal sanctuary in Bethlehem (c. 327-339) were built. It was the octagonal shape of the baptistery or baptismal font in many Christian buildings or ensembles that pointed at the symbolism of resurrection and new life (Martimort, 1987: 210).

Buildings with an elliptical plan were also built in the Roman period, the amphitheatres of the Empire being the outstanding examples. The Flavian Amphitheatre, known as Colosseum and built in 72-80, which was the most famous, could accommodate a crowd of 50,000 to 70,000 . Its plan's maximal dimensions reached $188 \times 156$ metres and the height of the external walls reached up to 49 metres. Other examples are the amphitheatres in Arles, Nîmes and Pula. Vitruvius, who had written his masterpiece nearly hundred years earlier, did not know these objects.

After the fall of the Western Empire in 476, in the nearly thousand-year-long Middle Ages, octagonal building plans were rare and ellipse plans almost never appeared. Exceptions were those objects of octagonal plans which referred by their shape to the antique symbolism of perfection. These include the San Vitale church in Ravenna, built in 526-547, the palace chapel in Aachen, built in 796-805 (Fig. 1), and the baptisteries in which the number ' 8 ' had an important role symbolising revival and infinity.

The popularity of both shapes reappeared in modern times. An example of the octagon's application is the crossing of the nave and the transept in the Santa Maria del Fiore Cathedral in Florence, the construction of which began in 1357 and was completed by Filippo Brunelleschi from 1420 to 1434. Another remarkable work based on the octagonal plan is the Santa Maria della Salute Church in Venice, which has a central-longitudinal plan. It was designed by Baldassare Longhena and built from 1631 to 1687 . Its main, central space and the surrounding ambulatory were both planned upon the octagon. In 1679, the brothers Giorgio and Giovanni Catenazzi designed a church in Gostyń in Wielkopolska, Greater Poland, that was strongly inspired by the Venetian pattern (Fig. 2). One could note 


\section{Q::: technical
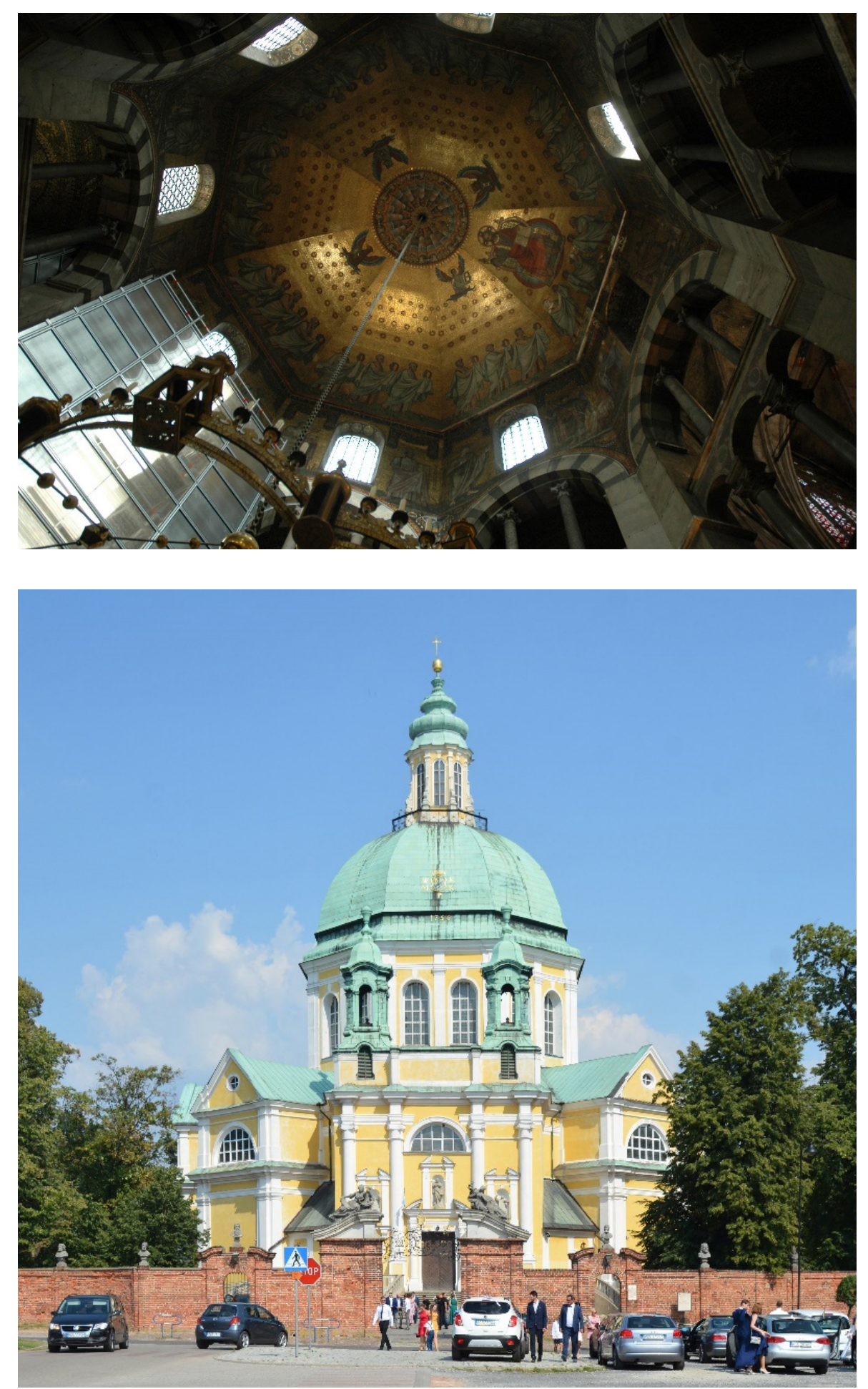

that within numerous concept plans of the so-called Ideal City, which were made from the fifteenth to the seventeenth centuries, the octagonal shape occasionally appeared in the plans of buildings which were proposed to fill the city.

The octagonal shape was used less frequently in later centuries, mostly (though not exclusively) for religious buildings, e.g., Buddhist or Christian. A non-religious example is Telok Ayer Market (currently known as the Lau Pa Sat building) in Singapore, which was designed by James MacRitchie and built of cast iron in 1894 to replace the previous structure, which was also octagonal.
Fig. 1. Interior of the palace chapel in Aachen, Germany, 2007 (photo by M. Motak)

Fig. 2. Church in Gostyń, in Wielkopolska, 2020 (photo by M. Motak) 


\section{::: technical E[transactions}

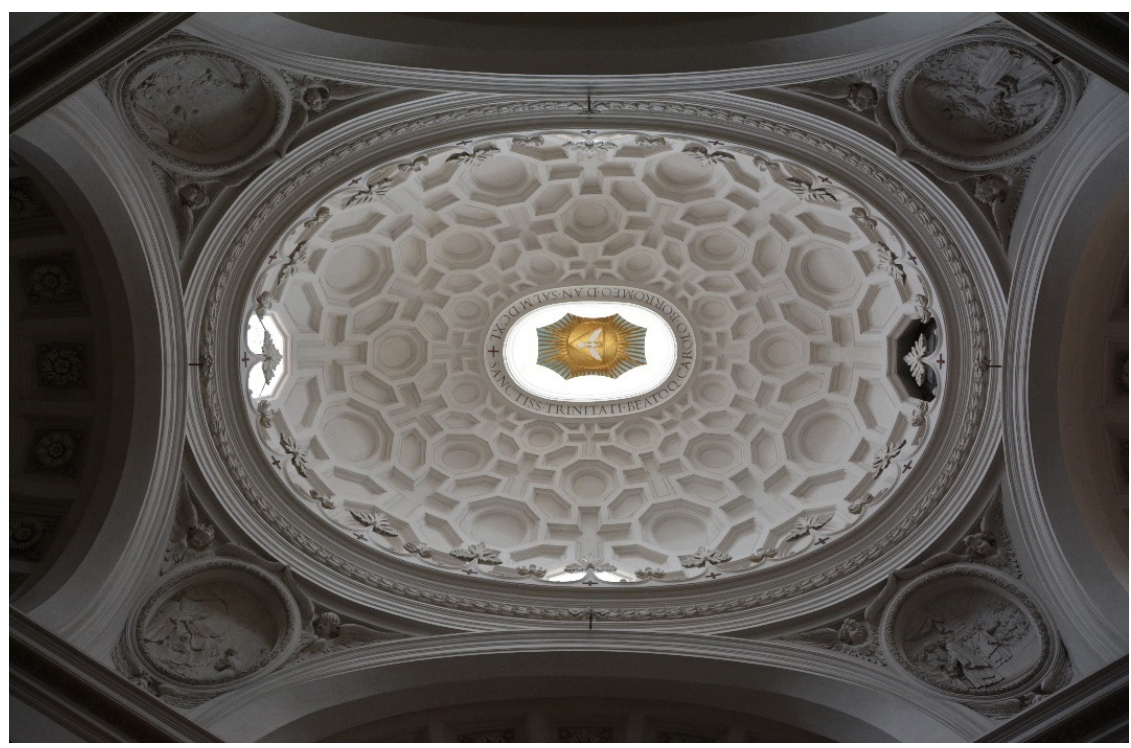

The ellipse motif in the building appeared in the Baroque period quite often. An especially beautiful example is the small church of San Carlo alle Quattro Fontane in Rome, designed by Francesco Borromini in 1637-1641 (Fig. 3), as well as the slightly larger church of San Andrea al Quirinale designed by GianLorenzo Bernini and built from 1658 to 1661. The ellipse motif was especially popular in the late stage of the Baroque era and its southern variant influenced by the Counter-Reformation and dominance of Roman Catholic Church. South German pilgrimage temples serve as examples: the church in Vierzehnheiligen (Basilica of Fourteen Holy Helpers), designed by Balthasar Neumann and built from 1743 to 1772 and churches by Dominikus

Fig. 3. Interior of the dome of San Carlo alle Quattro Fontane Church in Rome, 2017 (photo by M. Motak)
Zimmermann in Wies and Steinhausen. Churches with elliptical naves and chapels by existing churches were also built in cities, e.g. the church dedicated to Saint Charles Borromeo (Karlskirche) in Vienna (by Johann Fischer von Erlach, built from 1716 to 1737), the Elector's chapel in Wroctaw Cathedral (by Johann Fischer von Erlach, built from 1716 to 1724, Fig. 4), the Dominican Church in Lviv

Fig. 4. Elector's chapel at Wroctaw Cathedral,

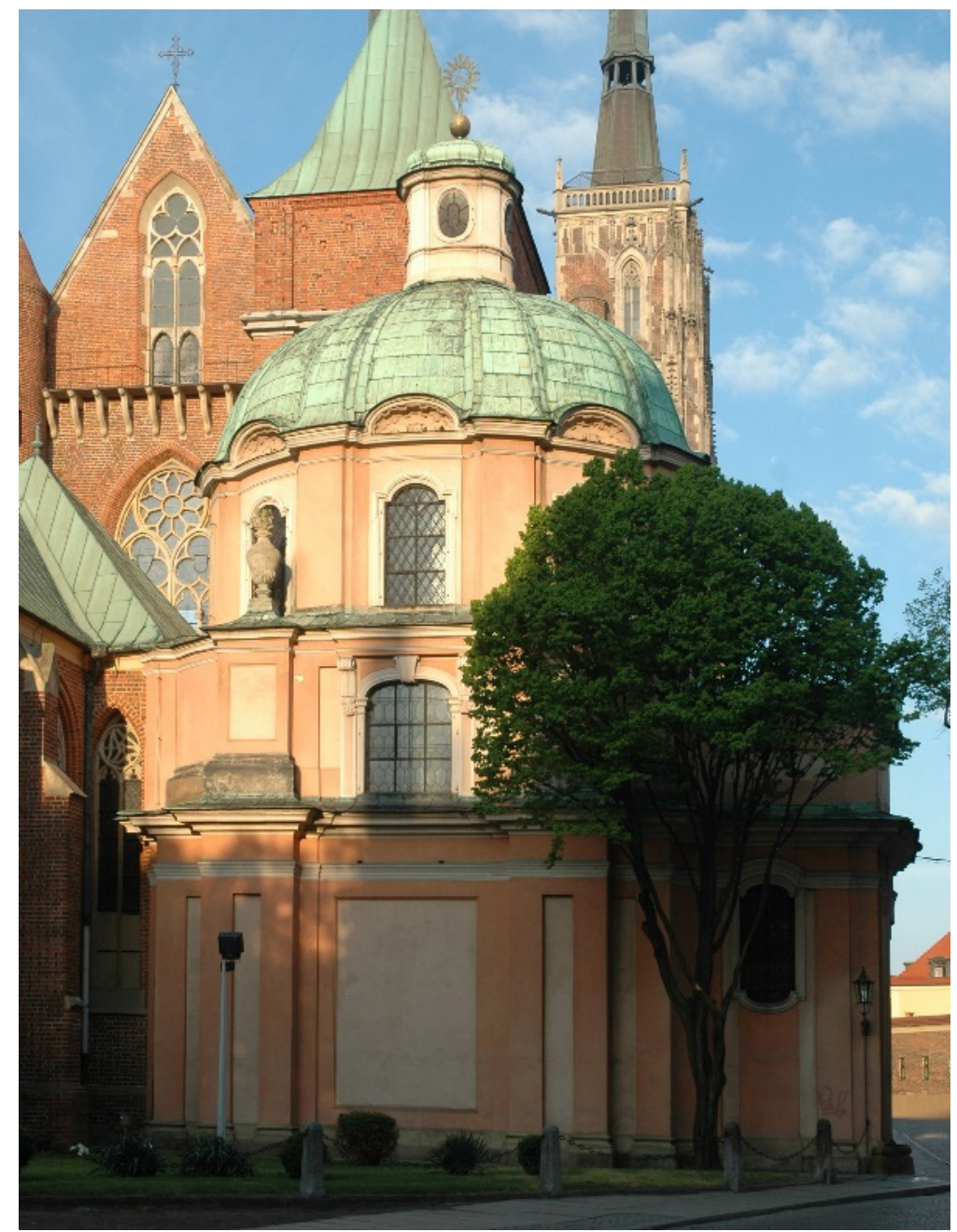


(by Jan de Witte, built from 1749 to 1764), the Holy Cross Lutheran Church in Rydzyna (by Ignatius Graff, built from 1779 to 1783).

After the Baroque style had passed, elliptical plans were rarely used. They came back at the end of the twentieth century. Examples of built projects include the Grand Palais convention centre in Lille (by Rem Koolhaas, 1990-1994) and the Divine Mercy sanctuary in Krakow-Łagiewniki (by Witold Cęckiewicz, 1997-2002).

\section{The beginnings of octagons and ellipses in the history of urban design}

Knowledge of the geometric shapes of both figures and their conscious use in order to form the building plans date back to antiquity and in modern times it was somewhat revived after a period of oblivion. However, the use of those shapes in urban design as a base of forming city squares is generally more recent and goes back to the Renaissance and Baroque times.

Octagonal city squares are seen in theoretical works by the Italian architects of the Renaissance period, in the fifteenth and sixteenth centuries. Early examples are the concepts of the city based upon the Vitruvian wind rose, such as the plan by Francesco di Giorgio Martini (discussed below). The built projects appeared, when the Baroque style dominated architecture and urban design. Most of the known octagonal city squares were built between the late seventeenth century and the mid-nineteenth century, i.e., in the late Baroque and Neoclassicism periods.

In turn, the city squares of elliptical shapes - unlike regular polygons - did not win more attention of the ideal city theoreticians ${ }^{2}$. One can also note that it usually took more time to see the completed elliptical urban projects than completed architectural projects. The majority of built elliptical city squares go back to the nineteenth and twentieth centuries; some have also been constructed in the twenty-first century. In some city squares designed in the sixteenth and seventeenth centuries, the ellipse was used; however, it was defined by the non-building elements of architecture, such as the floor of Piazza del Campidoglio in Rome or the colonnade of the Piazza San Pietro (the space in front of the Saint Peter's Basilica) in Rome (see also below).

\section{Review of built projects. Octagonal city squares}

Apart from the three somewhat model examples (Martini's concept project, Piazza del Campidoglio, Piazza San Pietro), a number of city squares was selected to be discussed and to illustrate the subject: eight with an octagonal plan and eleven with an elliptical plan. These belong to various periods and countries, constituting a selection of ideas and solutions within the range of the discussed subject. Both groups contain the examples of strictly octagonal or elliptical plans as well as examples whose characteristics have been altered to varying extents versus the basic geometrical shape, usually as a result of conscious decisions by their designers, to be distorted, reduced, or multiplied. The presentations of both groups are completed with a more detailed discussion of a Krakow case of a particularly original design.

Certain resemblance to ellipse some of the theoretical plans reveal probably resulted from searching for the most perfect polygonal form of city fortifications. Moreover, those forms were proposed later than the octagonal forms - in the $17^{\text {th }}$ century (see Münter, 1957). 


\section{口::: technical EDtransactions}

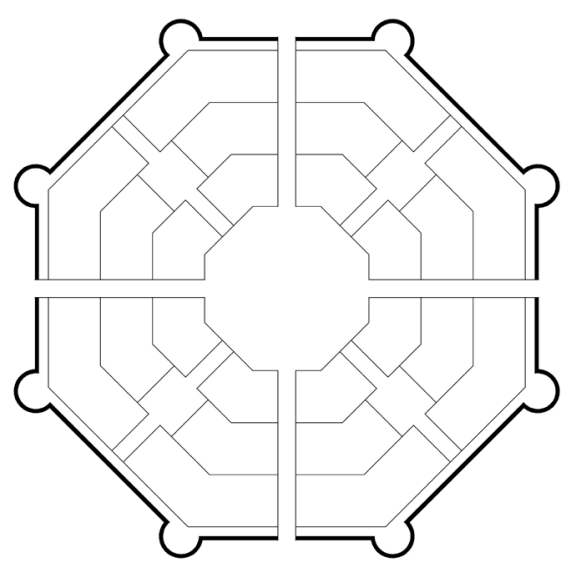

Fig. 5. Project of theoretical city plan of octagonal shape by Martini (drawing by M. Woźniczka)

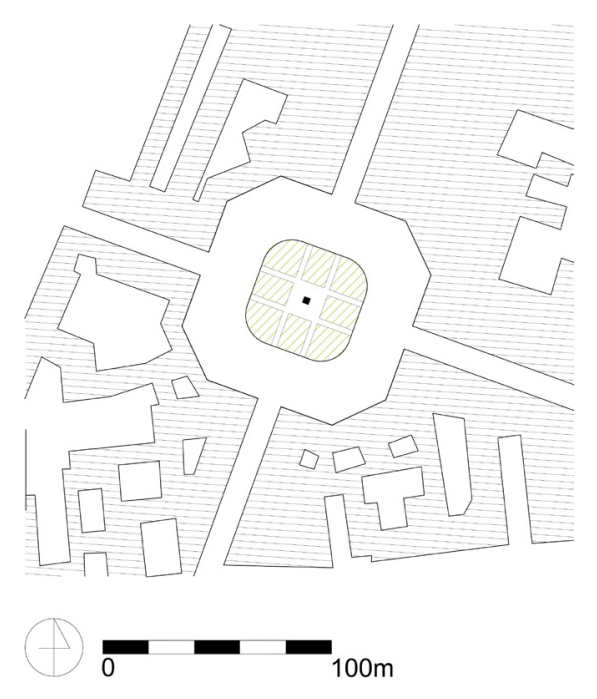

Fig. 6. Place Hoche in Versailles - plan (drawing by M. Woźniczka)

\subsection{Theoretical city plan according to Martini}

Francesco di Giorgio Martini (1439-1501) was responsible for the early theoretical city plans of octagonal shape (Fig. 5). He presented them in his treatise on the civil and military architecture, probably written shortly before

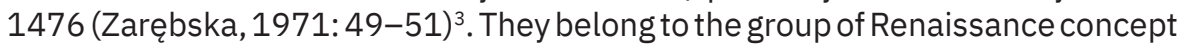
plans of radial and concentric features. If compared to most of the theoretical proposals, Martini's concepts stand out for his conscious distinction of the planned city location either on flat land or on hilly land. The other characteristic, which is especially interesting in these considerations, is Martini's joining of the octagonal form of the city square with the octagonal form of the entire city. Most of the ideal city theoretical concepts were dominated by the shapes of various regular polygons. However, if an octagon was considered, it did not necessarily concern the market square, with the most known concept being by Giorgio Vasari the Younger from 1598, which combined the centrally placed city square of a square shape with the city of an octagonal shape, although one of the city edifices designed by Vasari - a mint - was granted an octagonal plan (Zarębska, 1971: 141). Two elements of Martini's work were of special importance for many projects by various architects: he described how to create the radial system of the city and provided graphic schemes. In the descriptive section, Martini allows various forms of regular polygons, beginning with a triangle; however, the graphic schemes unambiguously reveal the principle of using the octagonal city square that is centrally placed within the octagonal city (Zarębska, 1971: 54-55).

\subsection{Place Hoche (originally Place Dauphine) in Versailles, France}

Place Dauphine was laid out within the city of Versailles, which was one of three components of a giant Baroque city-residence-garden ensemble that was built on the commission of King Louis XIV from 1661 via continuously added projects. In 1682, Versailles took over from Paris as the seat of the king and his court. There was a number of architects involved in the Versailles ensemble; the city part was probably Andre Le Nôtre's domain. However, it is also possible that the city was designed by Louis Le Vau (Gutkind, 1970: 118).

The plan of the city of Versailles resulted mostly from the juxtaposing of the vast three-axial plan upon the gridiron plan, with some variety added to the latter, e.g. city squares of various shapes. One of these is Place Dauphine (Fig. 6), which was designed c. 1671 at the junction of two axes running at right angles, north of the Place d'Arms (where three compositional axes crossed at a single point, making it the key place of the entire composition). The plan of the city square is perfectly octagonal, its opposite frontages c. 100 metres apart, are crossed by four streets. The city square is an important element of the city structure, combining compositional and functional values: "The plan [of the commercial and residential district] was developed around the octagonal Place Hoche, where the two principal streets met. This eliminated, at least partly, the difficulty of the diagonal limitation of this quarter (...)" as "The two main axes crossing the Place Hoche at right angles made the street pattern of this part more or less independent of its connection with the avenue" (Gutkind, 1970: 119).

Three- to five-storey buildings were constructed in the city square's frontages. One of four streets leading from the city square (the northernmost) was granted an impressive vista terminating with the Notre-Dame de Versailles Church, which was built in 1684-1686 according to the design by Jules Hardouin-Mansart. This north-south axis is functionally the more important of two theoretically equal axes since to the south, it leads towards the Place d'Arms.

The place was renamed in 1832 to honour General Lazare Hoche. The statue to the General was built in 1836 in the centre of the city square, at the intersection

3 Martini's Trattato di Architettura civile e militare (...) gained popularity during the author's life with the first incomplete edition but the full edition was published only in 1841. 
of two compositional axes. It became a compositional accent of Place Hoche; its localisation emphasising - by the front side with the face and the inscriptions the axis closed with the façade of the church (Fig. 7).

If considered with the Bogdanowski theory on the city interiors, Place Hoche's interior is undoubtedly of a closed ("concrete") type, with $13 \%$ of the openings of the perimeter being comprised.

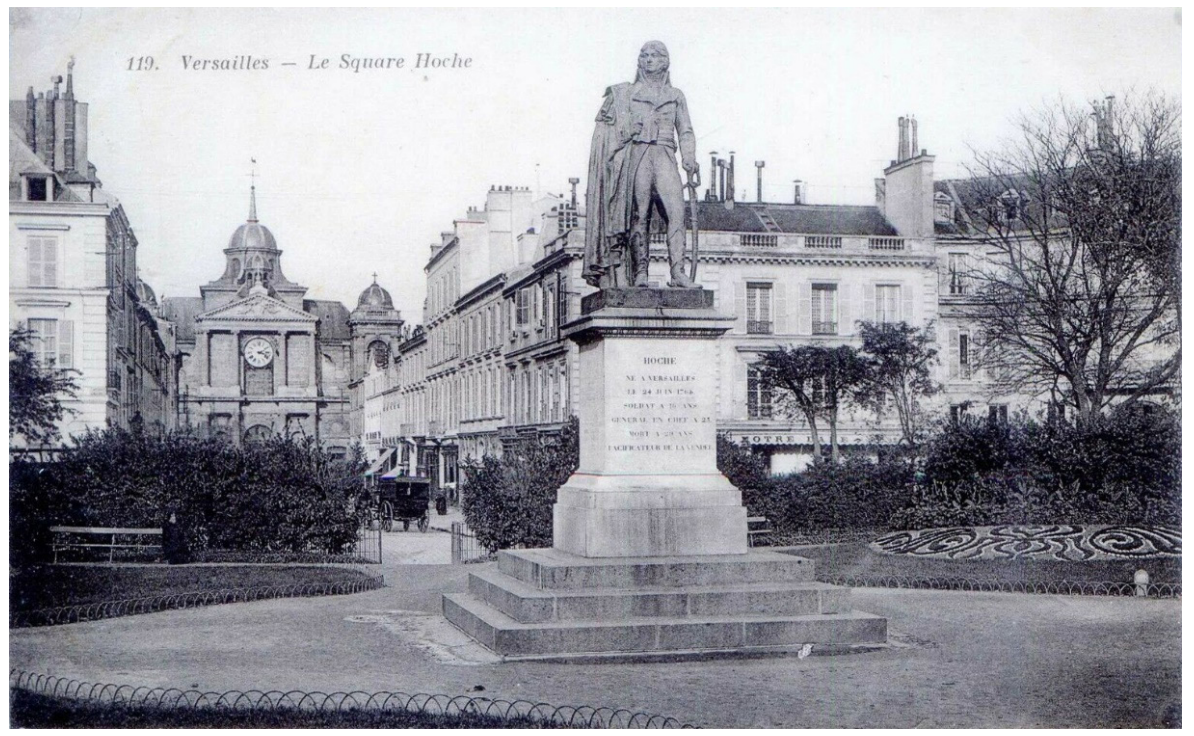

\subsection{Place Vendôme (originally Place Louis le Grand) in Paris, France}

The genesis of Place Vendôme in Paris (Fig. 8), the large-scale urban and architectural framing for the large equestrian statue of King Louis XIV dates back to 1685. In that year, the sculptor François Girardon started to work on the statue. It was, however, only in 1698 that the design of the city square was made, by Jules Hardouin-Mansart (1646-1708), to be approved and built. In 1699 , the statue was put in the centre of the emerging city square, i.e., at the intersection of two compositional axes. The longer axis was marked by the only two streets in the shorter frontages and the shorter axis was marked only with modest avant-corps in the longer frontages. The base of the statue and the figure were aligned with the main axis. The image of the city square frontages was strictly codified, imposing the individual investors with the uniform architectural features of façade; the façades were built first place before the rest of the buildings was constructed. The buildings around the city square were completed by 1720 . These were three-storey structures with shops on the ground floors and the especially exposed, tall main floor. An additional (fourth) floor, lit with rhythmic decorative dormers, was placed in the tall roofs.

This city square had a generally rectangular plan measuring c. 135 × 125 m; however, it was modified with diagonal cutting off of the corners (where there were no streets - each of these cuttings was around $20 \mathrm{~m}$. The inventive solution of the corners, which like the avant-corps of the longer frontages were topped with tympanums, was responsible for the final image of the city square together with the unique concept intended to provide the carefully considered spatial frame for the royal monument. This resulted in some problems with the definition of Place Vendôme's geometry. The notion of an octagon is used but usually in the context of the initial shape being a rectangle: "The plan of the Place Vendôme constitutes a rectangle with its corners cut off, thus creating an octagonal effect" (Morris, 1994: 199). However, the impressions created by the corners' shape are individual and may differ: "The square is a rectangle of 360 by 430 feet with truncated corners, which create the impression of concave corner" (Gutkind, 1970: 270).
Fig. 7. Place Hoche in Versailles, with the Notre-Dame de Versailles Church in the background. Postcard c. 1900 (source: https://picclick.fr/CP-78-Yvelines-Versailles-Le-Square-114206391145.html, date of access: 2021/04/25)

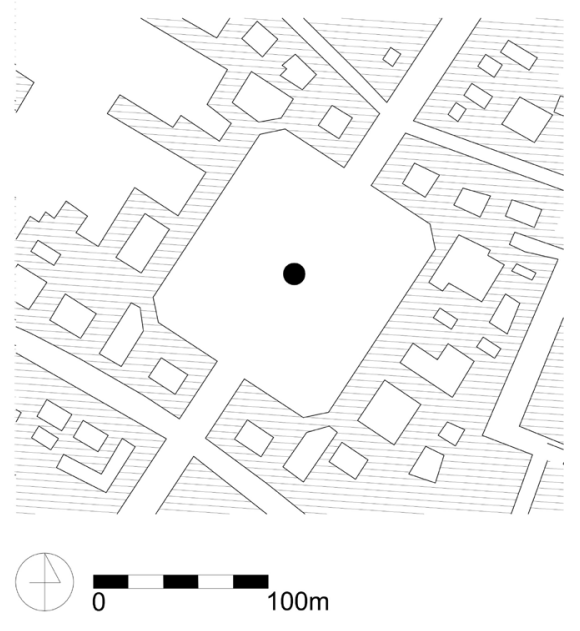

Fig. 8. Place Vendôme in Paris - plan (drawing by M. Woźniczka) 


\section{口:: technical EDtransactions}

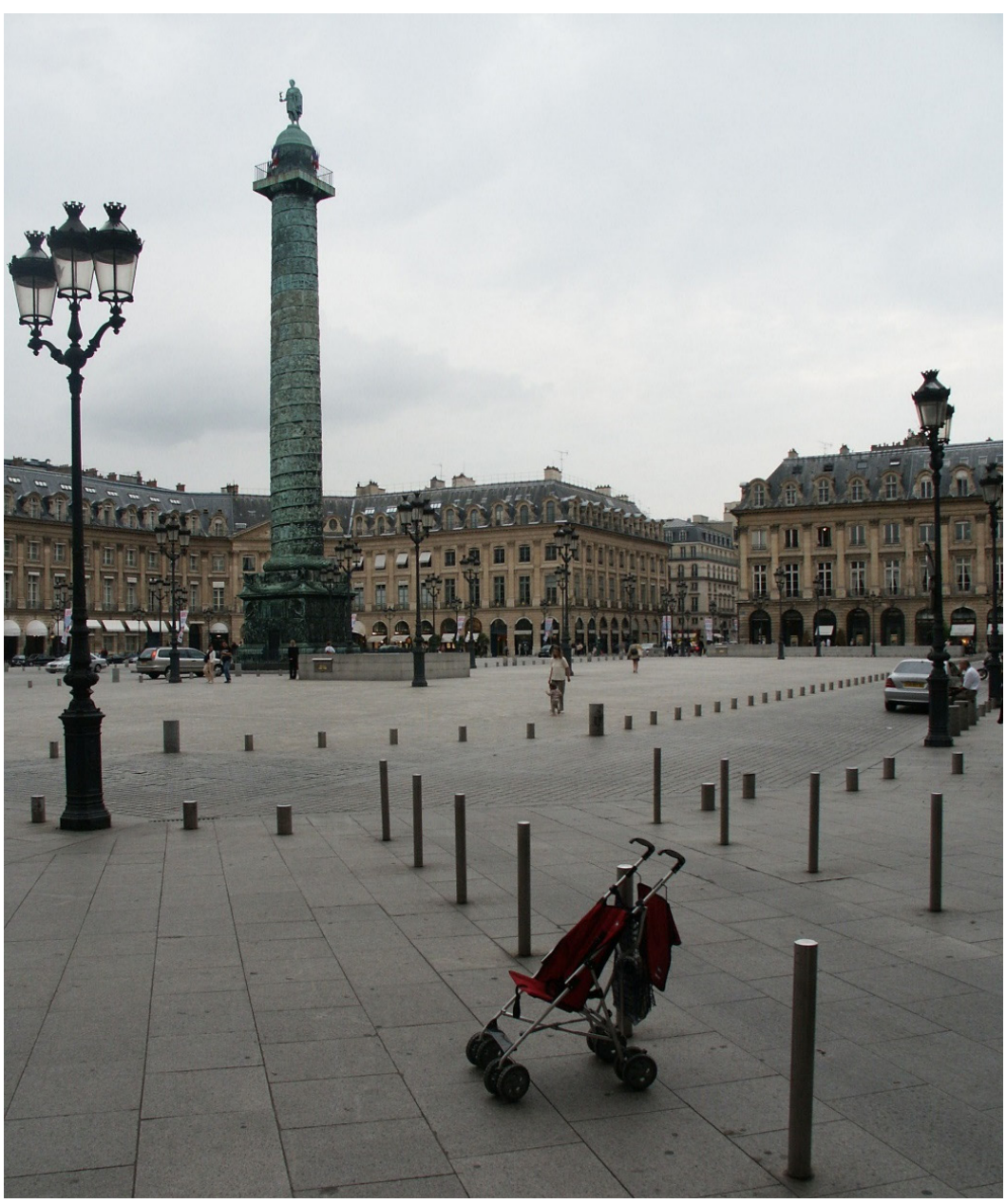

Fig. 9. Place Vendôme and Vendôme Column in Paris, 2003 (photo by M. Motak)

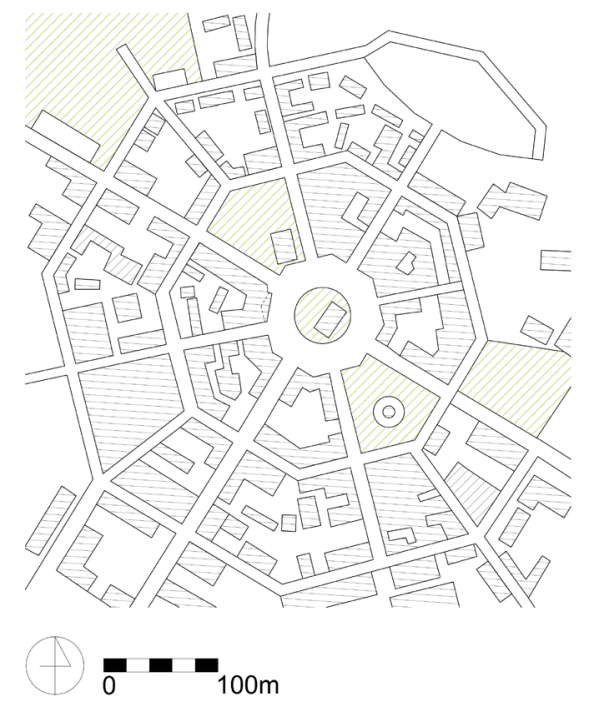

Fig. 10. Town-Hall City Square in Hamina plan (drawing by M. Woźniczka)
The equestrian royal monument was pulled down in 1789, during the French Revolution. In 1810, it was replaced with the Vendôme Column, decorated with the spiral bas-relief and topped with the statue of the Emperor Napoleon. The statue was removed in 1831 and replaced with a copy in 1863. The entire column fell in 1871 during the Paris Commune and was re-created in 1874. Regardless of the strictly political conditions of all these events, one should note the impact of the change on the urban orientation. The square plan of the column base replaced the rectangular plan of the equestrian statue base. The original statue's height was 17 metres including the base; the column's height is as much as 44 metres including the statue (Fig. 9). Due to it being higher than the roofs of the buildings, the column became an accent seen from a number of sites in Paris. Thus, from these places, one can note the focal point of that unusual city square with its shape being in between an octagon and a rectangle.

Apart from the replacement of the statue with the column and the construction of the underground car park, the latter being barely noticeable in the public space, the city square's image has not changed through 300 years of its existence. The interior is closed ("concrete"), with openings making up only $8 \%$ of the openings, and there are only two streets leading to the city square. As a result, it is perceived as one of the most closed interiors ever created among octagonal-plan city squares.

\subsection{Raatihuoneentori (Town-Hall City Square) in Hamina, Finland}

The octagonal Town-Hall City Square (Raatihuoneentori in Finnish) in Hamina (the city's historic name in Swedish - Fredrikshamn) was laid out and initially built-up from 1722 to 1724 (Fig. 10). The city square was the central part of the city with its radial plan, surrounded with the star fortress. Axel [von] Lőwen designed the entire city-fortress, which was of significant military importance. The new radial plan replaced the previous, gridiron plan. One of the urban historians called Hamina "One late survival of the Palmanova model" (Kostof, 1991: 190), probably referring to the radial plan of the fortress because on the same page he recalled an octagonal theoretical model by Martini, whereas the main city square of Palmanova is hexagonal and the entire city is nonagonal.

In 1798, the present town-hall was built in the centre of the city square; it has a rectangular plan and three storeys. It dominated the buildings surrounding the city square, most of them had one or two floors; two temples - Lutheran and Orthodox - stood out slightly. All buildings, with their limited scale and uniform form contributed to the harmonious interior of the city square (Fig. 11). The compositional ensemble in Hamina has been preserved in a very good condition and without any major urban change, though architecturally, some buildings were slightly extended. The interior of the city square is on the verge of being closed ("concrete") and semi-closed ("objective") with $30 \%$ of the perimeter comprised of openings. It seems to perfectly match the limited scale and modest architecture of the surrounding buildings. 


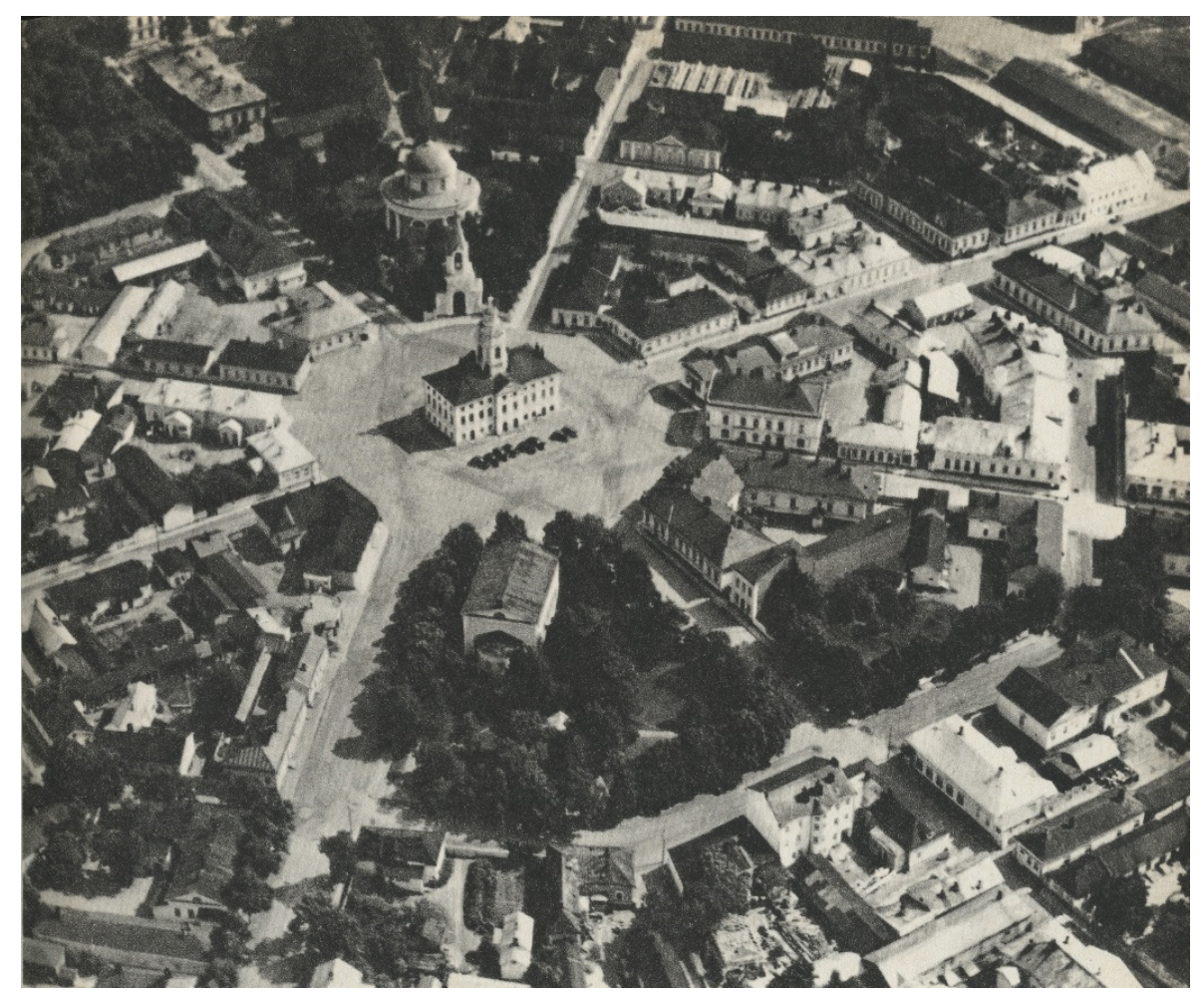

\subsection{The city square in Pokój (originally Carlsruhe), Poland}

The plan of the town of Pokój (which was called Carlsruhe from its foundation until 1946) in Silesia in Poland dates back to c. 1747. It was arranged around the palace of Counts of Württemberg, which was accompanied with a number of auxiliary buildings (Fig. 12). The town was granted an unusual star-like plan of eight compositional axes intersecting at one point, in the middle of the palace's square plan ( $24 \times 24$ metres). The palace, topped with a small dome, was built in the centre of the circular city square, its diameter being 116 metres. However, the flat façades of the buildings surrounding the theoretically circular city square resulted in it actually having an octagonal shape (Fig. 13). "Despite the stiffness of the perfectly regular plan, constituted of 8 arteries (former forest tracks) running radially from the octagonal central city square, the artistic gift of the architect who skilfully managed the space and urban detail (fences, gates) resulted in an interesting whole" (Szafer, 1955: 72)4.

Georg Ludwig Schirmeister designed the entire ensemble, while Klöber was responsible for the design of the gardens which surrounded the palace and occupied one of eight parts of the plan's external circle. The construction took place from 1750 until 1820. The ensemble in Pokój was a distant echo of the plan of Karlsruhe city in Baden-Württemberg in south-west Germany, where 32 compositional axes met at one place - the palace tower's central point.

All buildings around the city square as well as the palace itself were destroyed in 1945; their ruins were removed. Only a few buildings that stood further from the city square survived, including the Catholic and Lutheran churches which terminated the vistas of two radiating streets. The only remnant of the original city square's composition is the circulation scheme of the present roundabout, the scale of which is most unusual with regards to the scale of the small town and the lack of any buildings directly around it. The interior of the city square was originally semi-closed (25\% of the openings). However, due to it
Fig. 11. Town-Hall City Square

(Raatihuoneentori) in Hamina, aerial view (Piprek, 1988: 63)

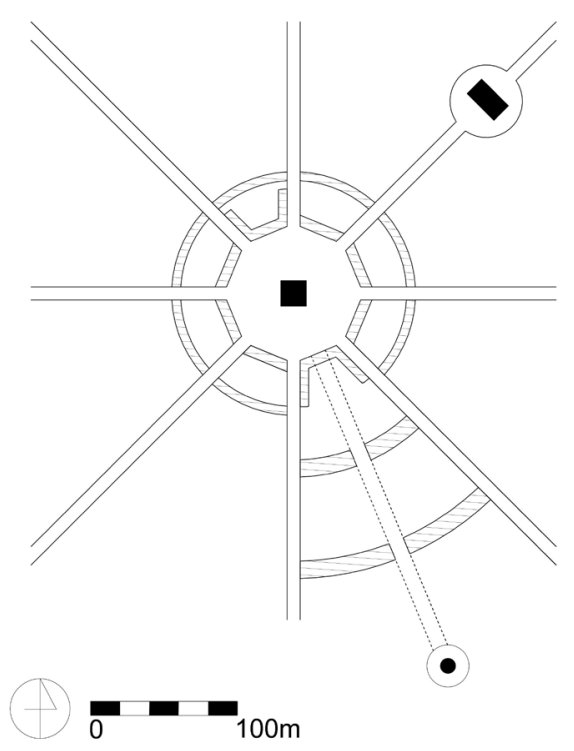

Fig. 12. City square in Pokój - plan in c. 1800 (drawing by M. Woźniczka)

$4 \quad$ Quotation translated by M. Motak. 


\section{::: technical

Fig. 13. City square in Pokój (then Carlsruhe, OS), aerial view (Königer 1938: 82)

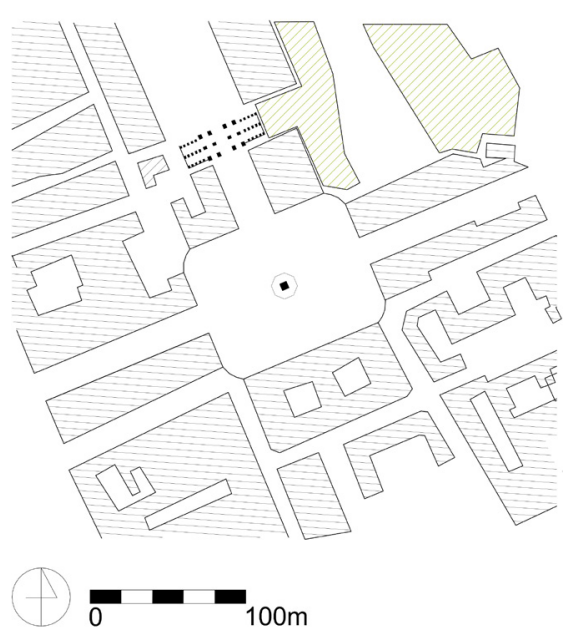

Fig. 14. Place Stanislas in Nancy - plan (drawing by M. Woźniczka) being destroyed and not reconstructed it is nowadays a semi-open or nearly fully open interior, with practically $100 \%$ of the perimeter being made up of openings.

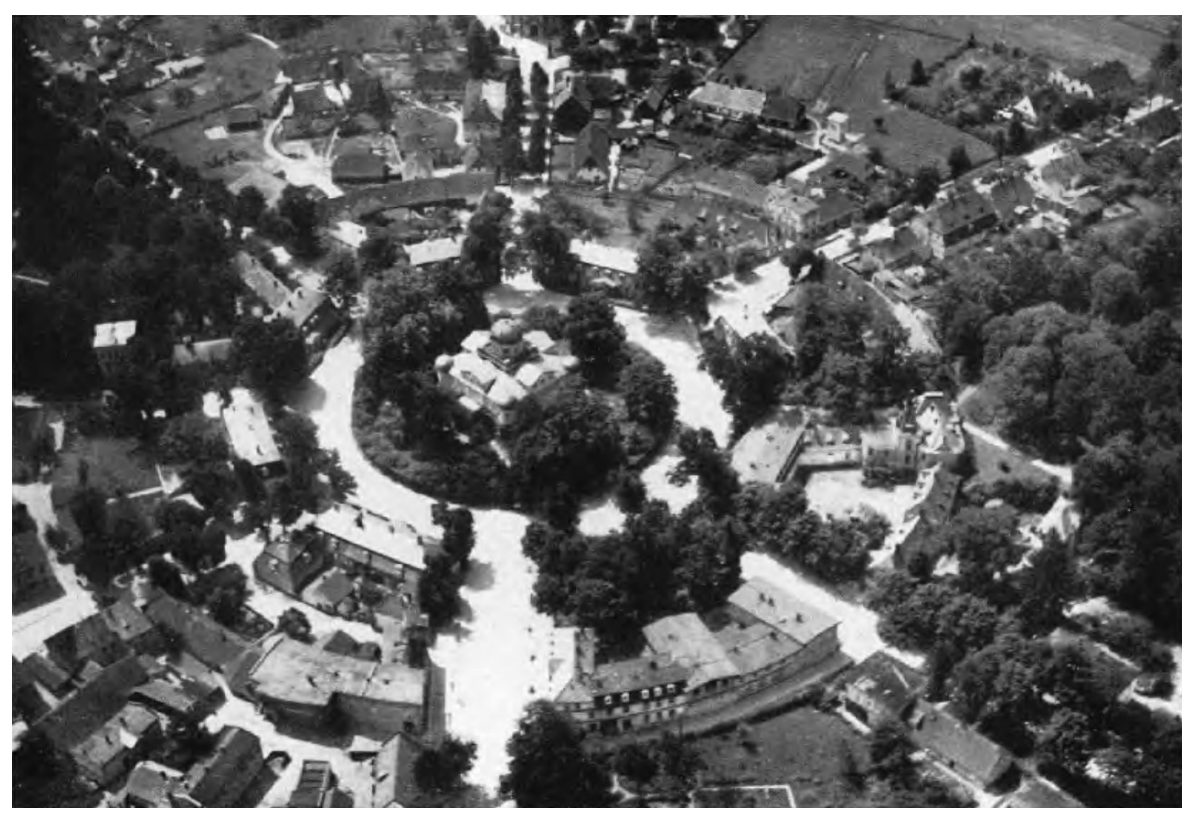

\subsection{Place Stanislas (originally Place Royale or Place Louis XV) in Nancy, France}

The Stanislas city square in Nancy (Fig. 14) was built from 1752 to 1755 as part of an urban composition consisting of three city squares. It was commissioned by Stanistaw Leszczyński, the former two-time King of Poland and the Grand Duke of Lithuania. Having twice lost power in the Commonwealth of Both Nations (Polish: Rzeczpospolita Obojga Narodów), from 1738 to his death in 1766, he was the Duke of Lorraine, where he turned out to be an efficient manager of the country and a patron of culture. Numerous monuments, street names and institutions commemorate Duke Stanislas. On his initiative, the capital of Lorraine - Nancy - was partly remodelled in the 1750s. The project, inspired by Leszczyński and drawn by architect Emmanuel Héré (1705-1763), resulted in an ensemble of three city squares: Place Royale (now Place Stanislas), Place de la Carrière and Place Hémicycle (now Place du Général de Gaulle). These city squares were of various shapes, sizes and frontages; however, they were subject to the continuous compositional axis and unified with small architectural details, such as fences and lamp-posts, which were made by hand by the local blacksmith artist, Jean Lamour. The localisation of the three-city-square ensemble on the edges of two once separate cities helped their spatial and social integration.

Place Stanislas is the only one of the three city squares of the Nancy ensemble, which is related to the octagonal shape, though to a lesser extent than other city squares discussed in this review. The Place Stanislas frontages, consisting of public buildings of various heights, surrounded a rectangle that is symmetrically crossed by the axes of the streets, but the rectangle's corners remained unclosed. The neighbouring corners of the buildings in each city square corner, around 20 metres away one from each other, were linked in the most original and subtle way, by the elements of small architecture, with Lamour's particularly outstanding black-and-golden fences of lavish, Rococo decoration (Fig. 15). The statue of King Louis XV was built in the centre of the city square only to be pulled down during the French Revolution. In 1831, the statue of Stanistaw Leszczyński was built in that place. This has been the only change that took place in the city square during nearly 270 years of its existence. 


\section{a:: technical

The ensemble of city squares in Nancy is commonly recognised as a masterpiece of urban design ${ }^{5}$. The favourable opinions also apply to particular sections, with the city square of Stanislas being most noticeable for its most ceremonial character. The urban historians noted an outstanding ability to combine the compositional and functional aspects of that project which was related to the shape it was granted: "the canted corners of Place Stanislas do open through elegant ironwork to street and gardens in an eighteenth-century contextual gesture" (Trachtenberg, Hyman,

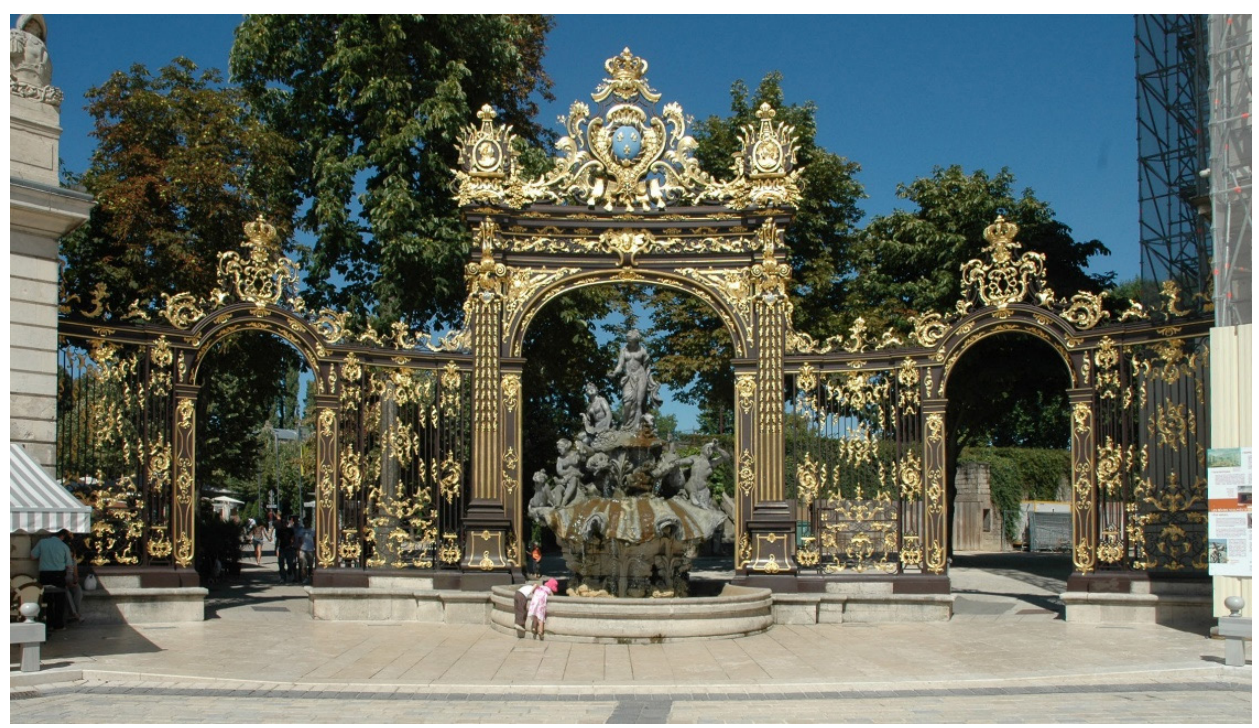
2002: 397).

The interior is closed ("concrete"), with $17 \%$ of the perimeter made up of openings. Moreover, there are contrastive though sensible links between the solid bodies of the buildings and the finesse and subtlety of the grates and other details in between the buildings.

\subsection{Amalienborg in Copenhagen, Denmark}

The Amalienborg in Copenhagen (Fig. 16) was built as part of a new district Frederiksstaden - formed in the mid-eighteenth century. The creation of the city's new districts was brought about by the continuous growth of the city and its population as well as by the patronage and ambitions of King Frederick $\mathrm{V}$ Oldenburg. The designs for the new district and its particular fragments were submitted by Nicolai Eigtved (1701-1754). He was a highly trained architect with training obtained in Rome, Dresden and Warsaw. He also took into consideration the suggestions of the patron - King Frederick - who insisted on regularity and order.

The city square (Fig. 17) is very regular and is surrounded by four identical palace buildings (erected in 1750-1760). The façades of the palaces have two bends at 45 degrees so as to create a regular octagon from the square. Four streets run between the palaces (one street is also crossed by the propylaea), resulting in two compositional axes crossing each other at the city square's midpoint. The axes, however, are of different importance. The north-south axis was designed parallel to the port embankment, which is around $150 \mathrm{~m}$ to the west of it. The east-west axis was granted more meaning since the Frederik's Church was built to the west of the Amalienborg and closed the view as seen from the city square. The church was designed by Eigtved, the construction began in 1749 to be completed, after partial redesigning, only at the end of the nineteenth century. The axis ran from the church to the port canal and the Dokøen (Dock Island) and was completed on the other side even later, at the beginning of the twenty-first century. On the other bank of the canal, the Royal Opera was built from 2001 to 2005 - a modernist edifice of large eaves over the façade along the canal. The compositional axis was strictly recognised and emphasised in the Royal Opera project by a prominent Dannish architect Henning Larsen (1925-2013). Thus, the axis was finally closed at both ends, with the church and the Royal Opera, each of the symmetrical façade.

See a compilation of opinions on the square and its impact upon the European squares (Ostrowski, 1996: 100-105).

Fig. 15. Place Stanislas in Nancy. Corner of the city square, 2009 (photo by M. Motak)

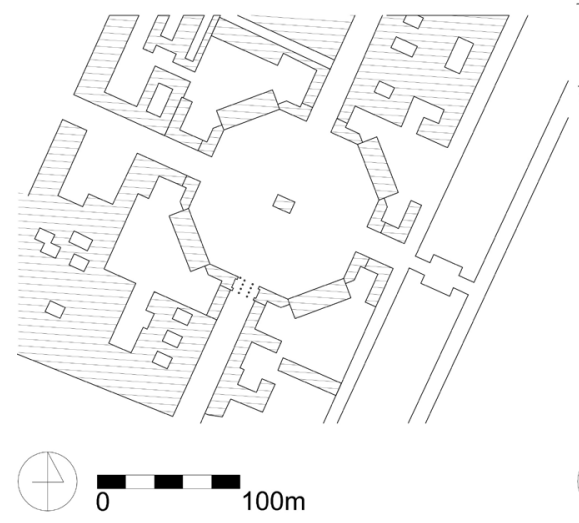

Fig. 16. Amalienborg in Copenhagen - plan (drawing by M. Woźniczka) 


\section{口:: technical Ëransactions}

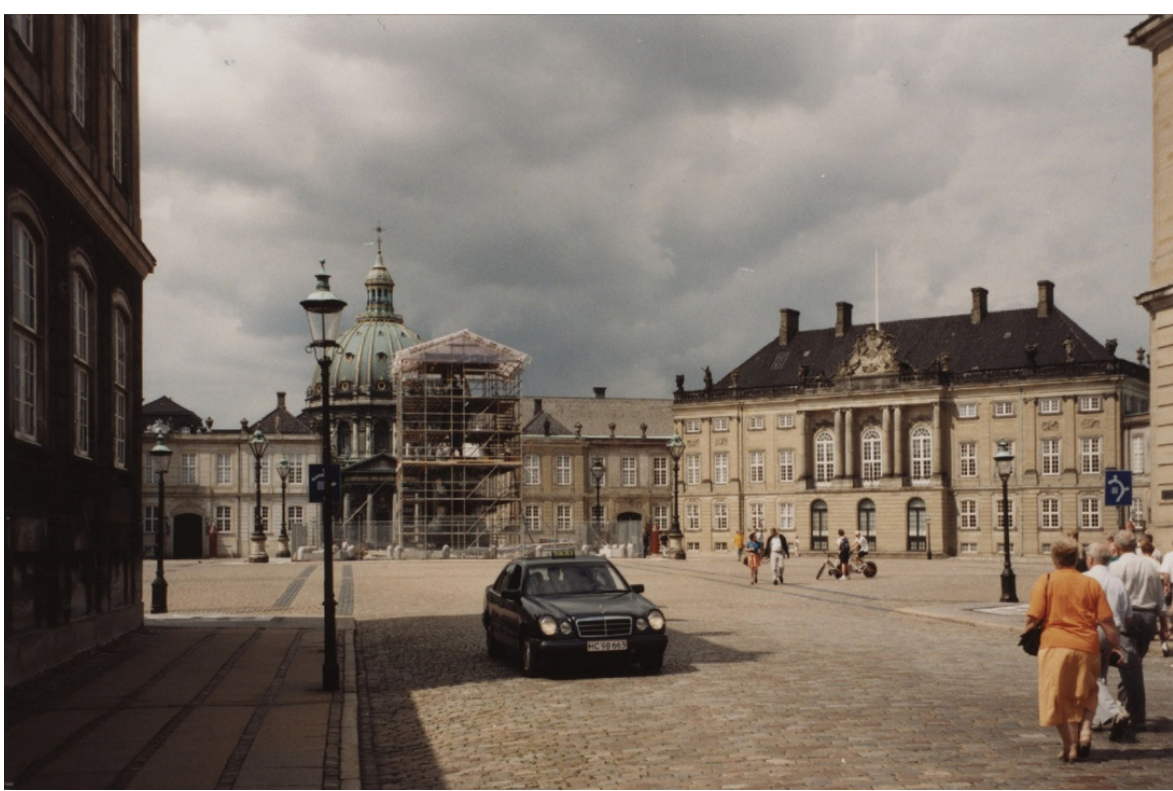

Fig. 17. Amalienborg in Copenhagen. The statue (in the scaffolding) and Frederik's Church in the background, 1997 (photo by M. Motak) opinion can also be quoted: "The ensemble is a typical product of eighteenthcentury formalism and lack of spontaneous inspiration, although its modest scale and reticence distinguish it favourably from grandiose ostentatiousness of other palaces of this period" (Gutkind, 1965: 320-321).

The interior of the city square is closed ("concrete"), with $18 \%$ of the perimeter accounted for by openings. As in the case of Place Stanislas, the ratio of 15 to $20 \%$ of the perimeter openings, combined with specially elegant architecture, seems to be most appropriate for expressing authority without being too overwhelming - a quality that must have been appreciated by the rulers of the Enlightenment period.

\subsection{Plac Wolności (Liberty City Square) in Łódź, Poland}

Plac Wolności in Łódź (Fig. 18) was laid out as Rynek Nowego Miasta (Market Square of New Town) between 1821 and 1823. The New Town was the first of the 1820s series of four projects for the textile industry that were laid in Łódź to the south of the fourteenth-century small town, which has been since called the Old Town. Of a dozen planned settlements founded in the region at the time, the Łódź projects' ensemble turned out to be most successful, with the nickname 'Polish Manchester'.

The city square was located in the centre of the New Town plan and it was crossed with the axes of streets. Its shape is octagonal and four streets are spaced at regular intervals with exits in every other frontage. The eastern exit was enlarged with a small plaza.

The southern frontage of the city square was granted the most special meaning. It was also the starting point of the nearly four-kilometre long, North-South Piotrkowska Street, along which the tódka project was laid out from 1824 to 1827 to be lined with modest houses for craftsmen. The street has been the main artery and the urban backbone of the city of Łódź for two centuries. Two buildings were erected from 1827 to 1829 on either side of the connection between Liberty City Square and Piotrkowska Street, which resulted in the symbolic gate into the southbound street. On the western side the New Town town-hall was built, while the Holy Trinity Lutheran Church was built on the eastern side. Despite their different functions, both buildings were given quite similar sizes and forms, which was possible in the Neoclassical style in which they were designed. Bonifacy Witkowski (1800-1840) was responsible for the design of both buildings. The author of the city square's design (and 
of the entire New Town plan) is not known; however, the sophisticated form suggests that it could have been a prominent architect, such as Chrystian Piotr Aigner or Jakub Kubicki (Koter, 1984: 59). "In accordance with the Classicist mainstream, canons and aesthetic tastes dominating the time, it was a regular and symmetrical plan" (Koter, 1984: 59) 6 .

The urban form of the city square has been preserved without any major change. The statue of Tadeusz Kościuszko, with its height of seventeen metres including the obelisk-like base, was built in the centre of the city square. The statue was destroyed during World War II in November 1939 and reconstructed

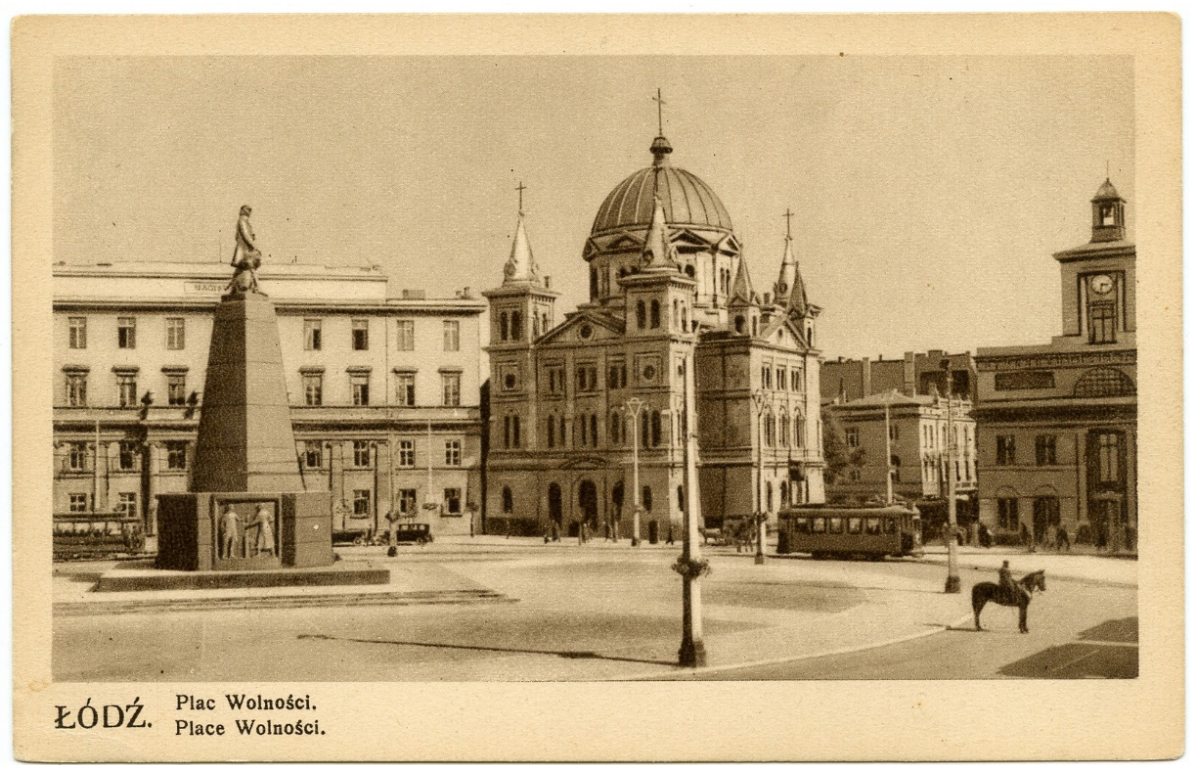
in 1960. It is a strong compositional accent, seen from all four streets leading to the city square, with the statue facing Piotrkowska Street.

Over the 200 years of the city square's history, architectural alterations have taken place in its frontages (Fig. 19). The buildings which surround the city square nowadays date back to different periods of the nineteenth and twentieth centuries. An important change resulted from the late-nineteenth-century substantial extension of the Lutheran Church (which became a Roman Catholic Church of the Descent of the Holy Spirit in 1945). Since the building of the former town-hall (housing the archives now) has maintained its original size, the enlargement of the church's volume led to the loss of balance of the city square's southern frontage. Apart from the town-hall and church, the municipality stands out on the south-eastern side; it acquired the present image in 1924-1925 (design by Wiestaw Lisowski) as a result of the remodelling of the 1856 - built School of Crafts (Olenderek, 2011: 24).

The interior of the city square is closed ("concrete"), with $15 \%$ of the openings in the city square's perimeter. The small extension of the open space on the eastern side helps the orientation in the entire space, despite not altering the general proportion.

\subsection{The city square of the Urzędnicze Estate in Krakow, Poland}

The city square of the Urzędnicze (Public Official) Housing Estate was designed in 1924 as part of the estate's regulation plan (Fig. 20) by Marian Lenk (1878-1961). It was the only city square of this small neighbourhood, which comprised four inner streets, four outer streets and 78 lots, of which 77 lots were intended for detached, semi-detached, and terraced housing, while one probably for a public building. The plan is a good example of garden suburb - a distant echo of garden city concept by Ebenezer Howard. 28 houses were designed and built by 1939 .

The city square was laid out in the central part of the estate. In the regulation plan, it was granted an unusual shape - an irregular, though symmetrical octagon. The city square's length (along the axis providing access from the nearby bridge and Krakow's centre) was 45 metres and the width varied from 22.5 to 75 metres. The city square was to be surrounded with terraced houses whereas all other parts of the estate were to be built up with individual or twin houses in the gardens. Ten terraced houses were planned in two rows, which were angled at the opposite ends of the frontages with houses of atypical, hexagonal plans

\footnotetext{
6 Quotation translated by M. Motak.
}

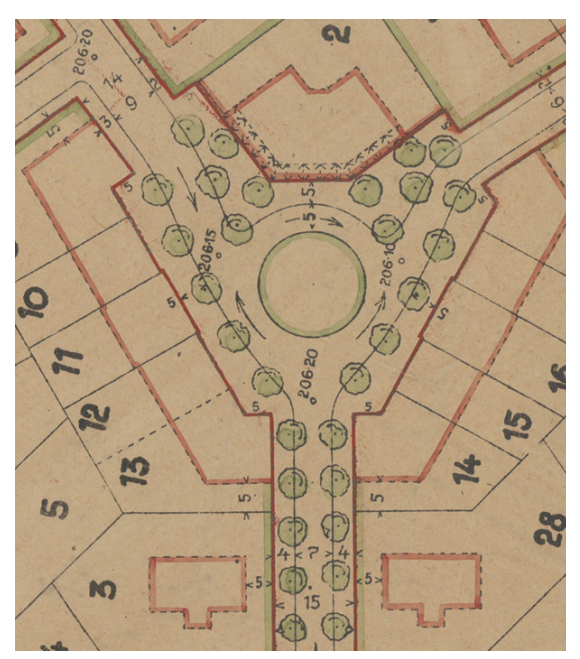

Fig. 20. The city square of the Urzędnicze Estate in Krakow, part of the regulation plan by Marian Lenk, 1924 (source: National Archives in Krakow) 


\section{a:: technical E口transactions}

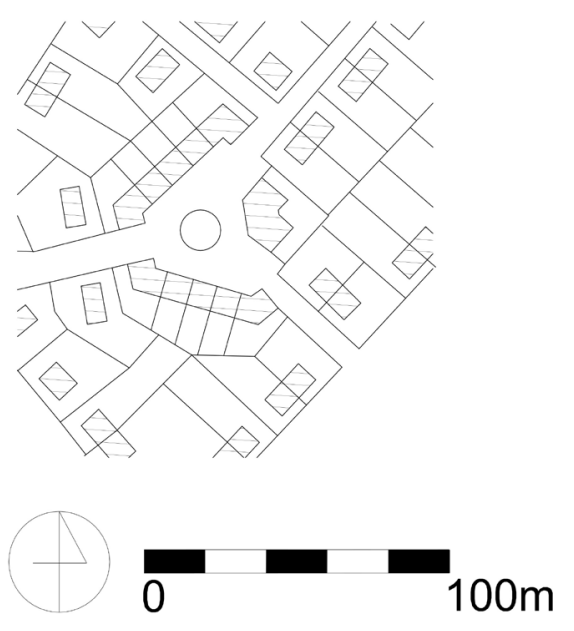

Fig. 21. The city square of the Urzędnicze Estate in Krakow (design) - plan (drawing by $\mathrm{M}$. Woźniczka)

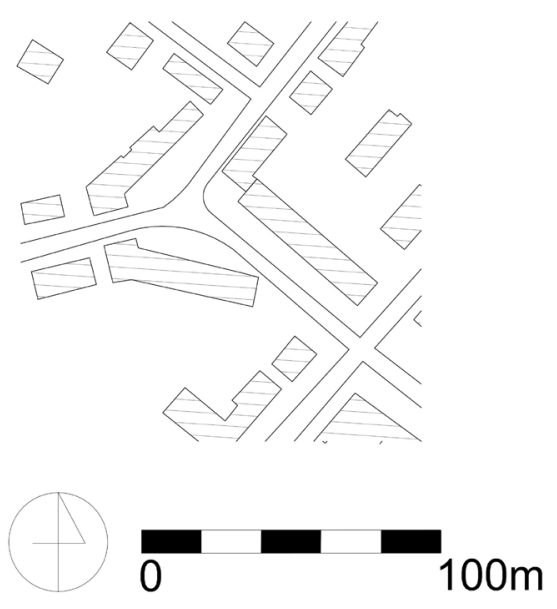

Fig. 22. The city square of the Urzędnicze Estate in Krakow (nowadays) - plan (drawing by M. Woźniczka) with larger avant-corps defining the city square's edges. The plans of the other buildings in the frontages were rectangular (nearly square). Shops or services were permitted on the ground floors of the slightly protruding middle buildings and the strongly protruding ones at the ends of the frontages. Four out of ten houses were built before World War II (1939-1945); two other designs were prepared but not built. Another frontage of the city square was to be formed in another way with a single free-standing building, situated axially, with a specific plan and façade bent twice. In that place, the building would play an important compositional role. The way it was shown in the regulation plan - its location, size and covered passages along its bent façade - suggest it was planned to house a non-residential function: public or commercial, or both. However, it was not constructed before World War II.

The city square of the Urzęnicze Estate never received an official name. However, from the very beginning of its execution it was necessary to refer to the city square in the administrative and planning documents. This is why in the designs of the houses (both drawings and descriptions) a number of names appeared, informal but recognisable: plac Potockiego, plac Antoniego Potockiego, plac Potockich? ${ }^{7}$. The name that seems to be most fascinating from the planning point of view, is the word rynek, which appeared sporadically in the 1930s documents of the estate. Since the Middle Ages, this word, a Polish equivalent for market square, has been reserved for city squares of special importance, some of which were the only city squares in the city and focused on most of the important city functions: administrative, commercial, religious, social ${ }^{8}$.

The 1924 regulation plan was no longer valid after World War II; however, until around 1960, it was usually considered informally. Two frontages of the city square were completed by the early 1960s, only slightly distorting the original idea. Then, in the 1960s, instead of one planned building, an ensemble of two buildings was built: the commercial-and-cultural two-storey-pavilion (by Kazimierz Chodorowski, designed in 1964) and the five-storey multifamily block (built from 1961 to1964, according to the design by Aleksander Nikodemowicz). The spatial mutual relationship between the two buildings, as well as their relationship versus the street leading to them axially, was entirely asymmetrical. Therefore it was highly contrastive with regards to the original concept created by Marian Lenk in 1924 (Motak, 2018, 2020). In the later period, after 1970, the city square did not undergo any major transformation (unlike the rest of the neighbourhood), but was more dependent on the local traffic, which reduced its public character.

The interior of the city square, both in the planned version (Fig. 21) and the existing version (Fig. 22), is closed ("concrete"), with 21 and $22 \%$ of the perimeter openings, respectively - and also surprisingly, since such a substantial distortion of the original form concept did not influence the discussed space in a statistic way but "only" in an aesthetic way.

\subsection{Conclusions concerning city squares of octagonal plans}

The city squares of the octagonal plan feature closed and static compositions.

The octagonal city squares are always symmetrical with at least one line of symmetry. Most of them, however, have two lines of symmetry, and some of them have four (Place Hoche, Amalienborg) or eight (in Pokój).

Documentation of particular projects in the Urzędnicze Estate area in the National Archives in Krakow. The Polish word "plac" means "square" or "plaza". Antoni Potocki had been the owner of land which in 1923 he gave to Towarzystwo Osiedli Urzędniczych (Association of Public Officials Housing Estate, a cooperative responsible for the entire estate project).

8 In Krakow, it has been assigned to the squares of Medieval origin (Rynek Gtówny, Maty Rynek, Rynek Kleparski) as well as to the squares of eighteenth- and twentieth-century towns and suburbs that later became districts of Krakow (Rynek Podgórski, Rynek Dębnicki, Rynek Fałęcki). 
Two- or four-axial symmetry of the city square's plan is accompanied with the symmetry of the street exits distribution. There are either four or eight street exits and they are equally distributed with angles between them of 90 or 45 degrees, respectively. Occasionally, there might be only two streets (Place Vendôme) or another principle of exit distribution (Place Stanislas).

Due to their stately and symbolical character, the octagonal city squares have predilection to express important contents and ideas: state, military, religious, cultural. And especially to manifest the power and role of the hero or patron of the city square's creation.

There is a strong tendency to place the compositional accent - the statue in particular - exactly in the centre of the city square unless a building had already been built there. No other location of that accent is used for.

In some cases (Place Vendôme, Place Stanislas), the first statue was built at the very beginning and helped the city square emerge, but in most cases, it was added later to the already existing city square and surrounding buildings.

In a few cases, a building rather than a statue was erected in the central area of the city square. The building's plan could be rectangular (in Hamina) or square (in Pokój).

The form of the statue or other compositional accent emphasises (with its own axis if it has one) the direction of two or four directions of equal importance, which was intended to be more highlighted for functional or symbolical reasons.

In very few cases, the octagonal city square features a form and proportions that differ from the canon discussed above, for example, the city square of the Urzędnicze Estate, though even in this case, one axis of symmetry has appeared.

\section{Review of built projects: elliptical city squares}

For the discussion of elliptical city squares, comparable principles presented at the beginning of the review of octagonal city squares are used.

\subsection{Piazza del Campidoglio in Rome and its inspirations}

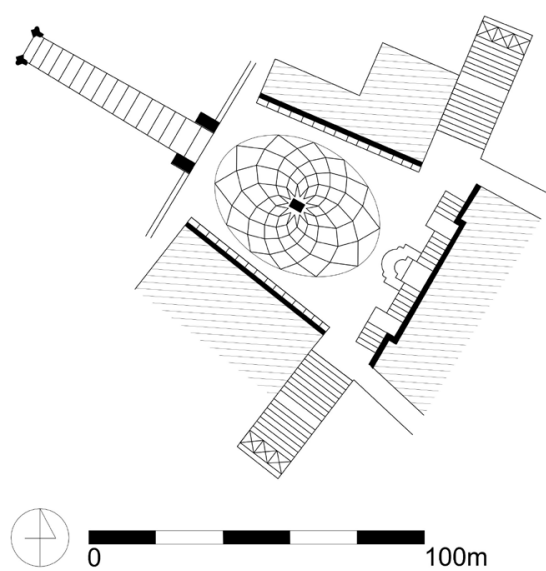

Fig. 23. Piazza del Campidoglio in Rome - plan (drawing by M. Woźniczka)

Piazza del Campidoglio in Rome (Fig. 23) is one of the earliest modern examples of the use of an ellipse in a city square space. This project was designed by Michelangelo in 1536. His main point was to arrange the buildings on the Capitoline Hill and create a new entrance to the city square. The ellipse, in the form of a drawing in the floor plane, was introduced as an element which integrates the interior. The equestrian statue of Marcus Aurelius in the centre was underlined with diagonal lines filling the ellipses.

Although the interior does not have an elliptical shape, the ellipse is an essential element of the urban composition of Piazza del Campidoglio. The individual elements

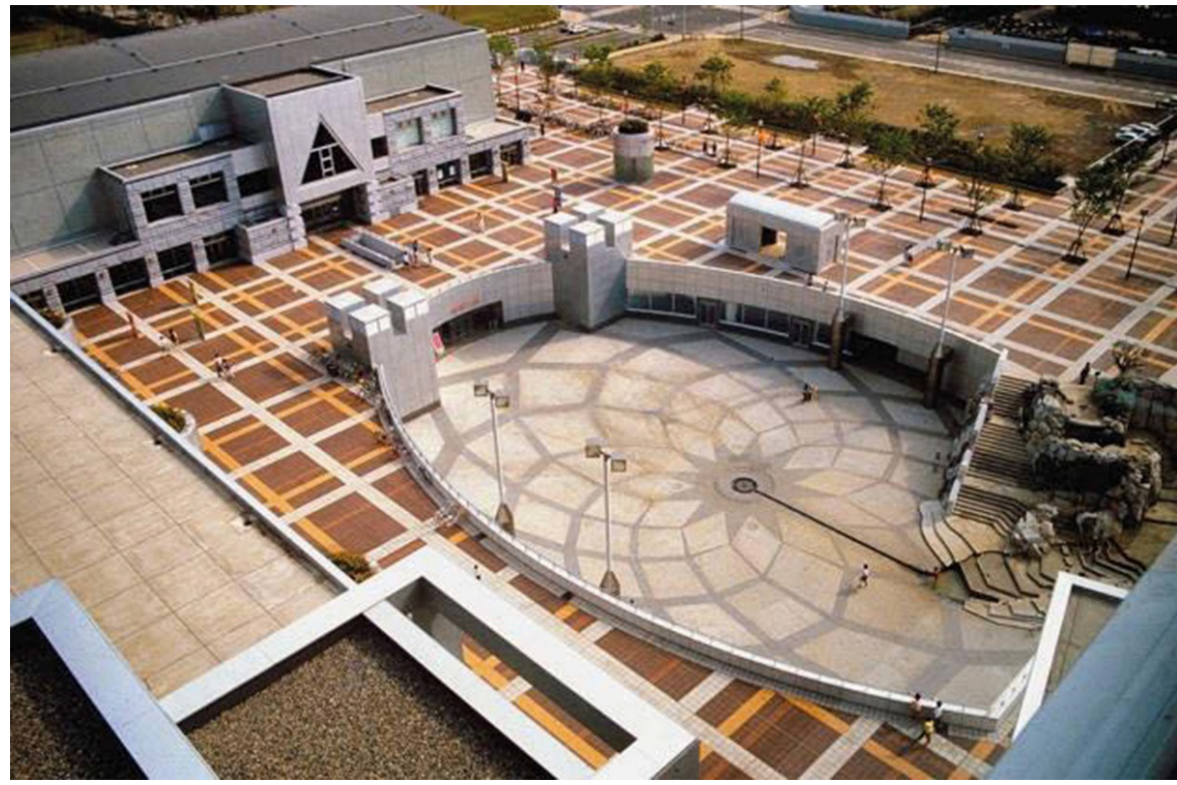
of the city square were completed in the seventeenth century. An exception was the floor which was made in the first half of the twentieth century. Arata Isozaki referred to the elliptical shape on the floor of Piazza del Campidoglio in the project of the city square in Tsukuba near Tokyo (1983) (Fig. 24).

Fig. 24. A. Isozaki, Tsukuba, 1995 (Ingarden, 2020) 


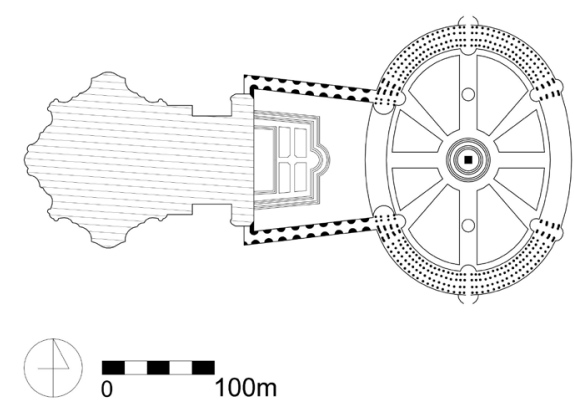

Fig. 25. Piazza San Pietro in Rome - plan (drawing by M. Woźniczka)

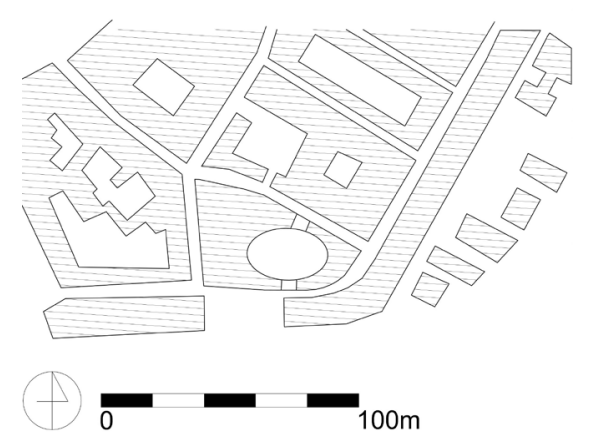

Fig. 26. Piazza Nuova in Bagnocavallo - plan (drawing by M. Woźniczka)

\subsection{Piazza San Pietro (St. Peter's Square) in Rome, Italy}

The city square in front of Basilica San Pietro in Rome (Fig. 25) was designed by Gian Lorenzo Bernini in 1655. The work is an example of the connection of an elliptical with a trapezoidal city square. The elliptical interior was created by the colonnade. It was a compositional complement to the project of Basilica San Pietro designed by Carlo Maderno in 1607-1612. The architecture of the basilica was accentuated by a series of three city squares.

The first was Piazza Retta - a trapezoidal city square directly in front of the basilica.

The second was Piazza Obliqua - the discussed elliptical city square. The intersection of the ellipse axis was emphasised with an obelisk and the foci are accentuated with two fountains (Bernini, D. Fontana).

The third city square - Piazza Rusticucci, was initiated in the seventeenth century and completed in the twentieth century.

\subsection{Piazza Nuova (New Square) in Bagnacavallo, Italy}

Piazza Nuova (Fig. 26) is located in the city of Bagnacavallo, in the province of Ravenna. Bagnacavallo was originally known as the Roman Castrum Tiberiacum (Malpeli, 1806; Cervelatti, 1991). The largest development of the village took place in the thirteenth to fifteenth centuries (Comune di Bagnacavallo, n.d.). The creation of the city square was a consequence of the need to locate meat trade and slaughter in a closed and controllable space.

The city square was built in 1759 (Cervelatti, 1991: 185). Its boundaries are marked out by a portico made of thirty arches. They form an ellipse with dimensions of $35 \times 20$ metres. In two of the arches, located on the shorter axis of the ellipse, there are entrance portals. However, the introduced gates do not create openings that stand out from the arcades surrounding the city square. As a result, the interior is perceived as completely closed ("concrete") with the surrounding elements (Fig. 27).

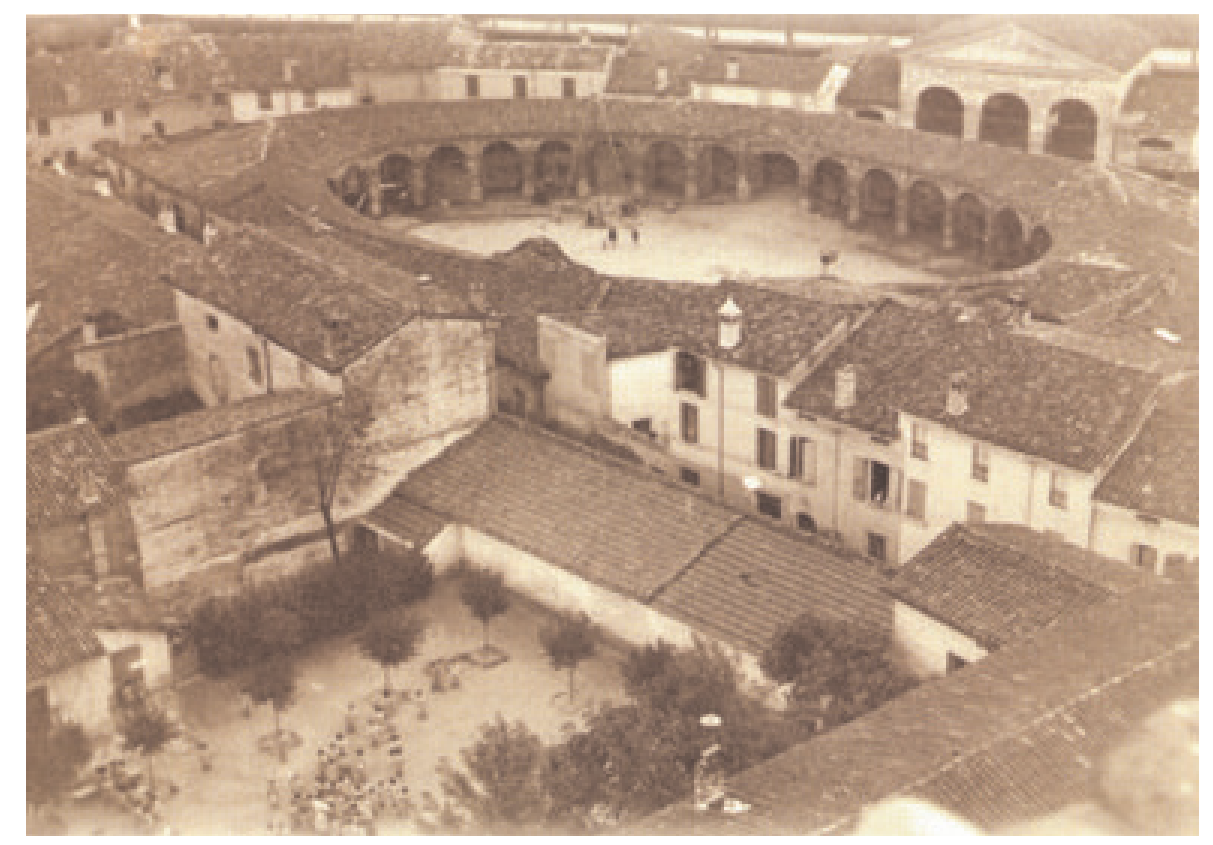

Fig. 27. Piazza Nuova in Bagnocavallo (source: https://www.bagnacavalloproloco. it/bagnacavallo-ieri/, date of access: 2021/03/01) 


\subsection{Prato Della Valle in Padua, Italy}

Prato Della Valle in Padua (Fig. 28) is one of the largest city squares in Europe it has an area of 88.620 m² (Zava, 2018; Gómez, Moral-Andrés, 2017: 85-106; Puppi, Toffanin, 1983: 163).

The site is located among the historical buildings of Padua, about 400 metres from the thirteenth-century Basilica of St. Anthony. Until the seventeenth century, this area was not developed in a specific way. Today's form of the city square has its roots in the activities of the eighteenth century. Works at that time were led by Andrea Memmo, the governor of Padua in 1775-1776 (Pasquali, 2009).

The centre of the city square is a paved ellipse. It is surrounded by a green area, a water canal and a second green belt. The intersection of the ellipse axis is accentuated with a fountain. The elliptical course of the canal is emphasised by sculptures on both banks. The site measures approximately $180 \times 240$ metres. The city square is closed by buildings that create a space with a shape similar to a triangle. Openings in the walls of the interior - mainly street inlets, constitute $34 \%$ of the city square's perimeter. As a result, the city square, according to Bogdanowski's theory, is defined as a semi-closed ("objective") interior. It is not an ellipse-shaped public space, but the elliptical composition introduced into the plan is the most important element.

The view of the designed Prato Della Valle was engraved by Francesco Piranesi (Fig. 29) (Zaggia, 2010: 112-128). Johann Wolfgang Goethe wrote down his feelings about Prato Della Valle in Italian Journey. In the notes of September $17^{\text {th }} 1786$, he predicted the future beauty of the still unfinished city square:

The great square, called Prato della Valle, is a very wide space (...). The wooden booths in the middle of it do not produce the most favourable appearance, but the inhabitants assure me that there will soon be a Fiera of stone here, like that at Verona. One has hopes of this already, from the manner in which the Prato is surrounded, and which affords a very beautiful and imposing view. A huge oval is surrounded with statues (...). A moat filled with water goes around the oval. On the four bridges which lead up to it stand colossal figures (...). It will perhaps form a very beautiful Prato, when the wooden Fiera shall be removed, and one built of stone, according to the aforesaid plan (Goethe, 1885: 50-51).

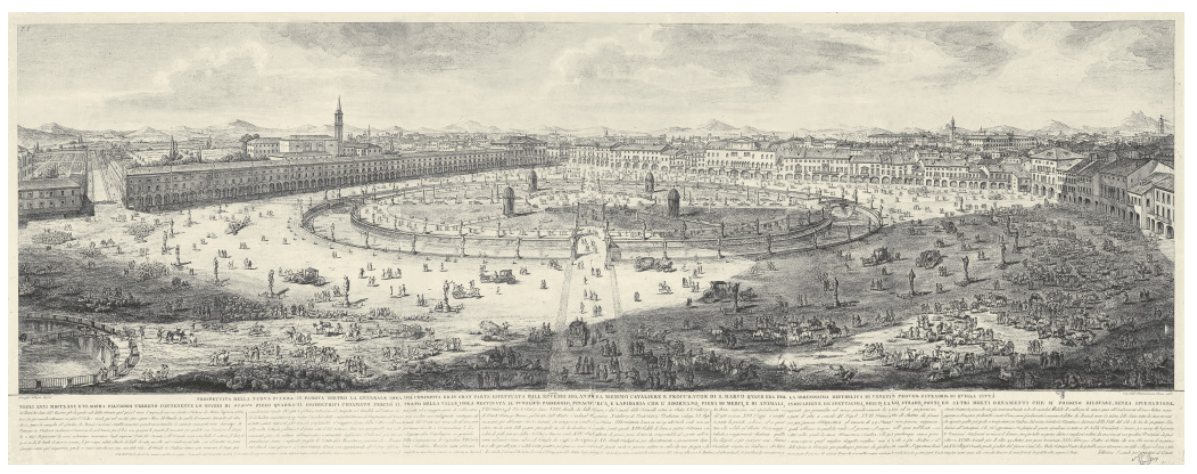

The delight of Prato Della Valle was also expressed by Melchiorre Cesarotti an 18th century Italian translator and poet. He described Memmo's plan in the following words: "He [Andrea Memmo] invented a vast and wonderful plan, but well digested and well connected in all their parts (...) plan designed to revive the industry, to wake art, to deepen the union and the community, to make the city right, delightful and admirable for foreigners (...)"9.

Il puro Omaggio. A suaeccellenza Andrea Memmo. Dedica, Padova, Penada, 1776, da cui sicita p. VII, (after: Zaggia, 2010: 114). Quotation translated by M. Woźniczka.

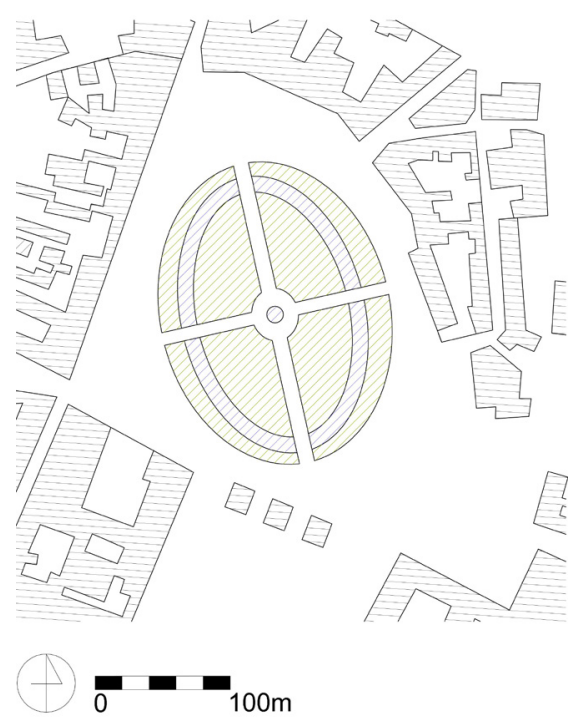

Fig. 28. Prato Della Valle in Padua - plan (drawing by M. Woźniczka)

Fig. 29. F. Piranesi, Perspective of the new Piazza in Padua behind the general idea (Zaggia, 2010) 


\section{::: technical EDtransactions}

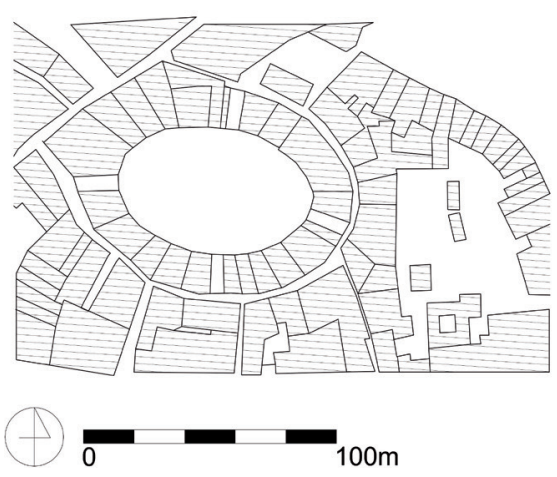

Fig. 30. Piazza Dell'Anfiteatro in Lucca - plan (drawing by M. Woźniczka)
Fig. 31. Piazza Dell'Anfiteatro in Lucca (Donati, 1978: 61)

\subsection{Piazza Dell'Anfiteatro (Amphitheatre City Square) in Lucca, Italy}

Piazza Dell'Anfiteatro (Fig. 30) was founded inside the ring of Lucca's walls from the $16^{\text {th }}$ century. Originally, a Roman amphitheatre was located in the place of the city square. In the Middle Ages, the market square began to take shape (Tesorid'Italia, 1975: 182). The current structure owes its form to Lorenzo Nottolini - the creator of the Piazza Dell'Anfiteatro project (1828) (Mazzarosa, 1843: 84). Until the implementation of Nattolini's idea, the city square had the form described by August Moszyński - king Stanistaw August Poniatowski's architect. Moszyński included his comments on the Lucca market in his Journal of Travel to France and Italy (1785). He described the still disordered Piazza Dell'Anfiteatro as follows: "Remarkable monuments of antiquity are the traces of the amphitheatre, incorporated into the walls of houses built in its place. Perfectly distinguishable oval shape (...) arcades and strengthening elements are visible (...). It can be assumed that it was a beautiful building, assessing the stones protruding from their homes" (Moszyński, 1970: 156) ${ }^{10}$.

The architect Lorenzo Nottolini arranged the buildings around the city square by adapting the façades of the surrounding tenement houses to the form of the former amphitheatre (Fig. 31). The inner ellipse measures approximately $75 \times 50$ metres. The edges of Piazza Dell'Anfiteatro are strongly marked. Only four of the tenement houses are hiding breakthrough entrance gates. The passages are only slightly larger than the shop windows on the ground floors of the building surrounding the city square. The passage and the windows also have the same form, topped with an arch. Entrance gates do not interfere with the impression of closing the city square. Thanks to this, it has a closed ("concrete") form without openings.

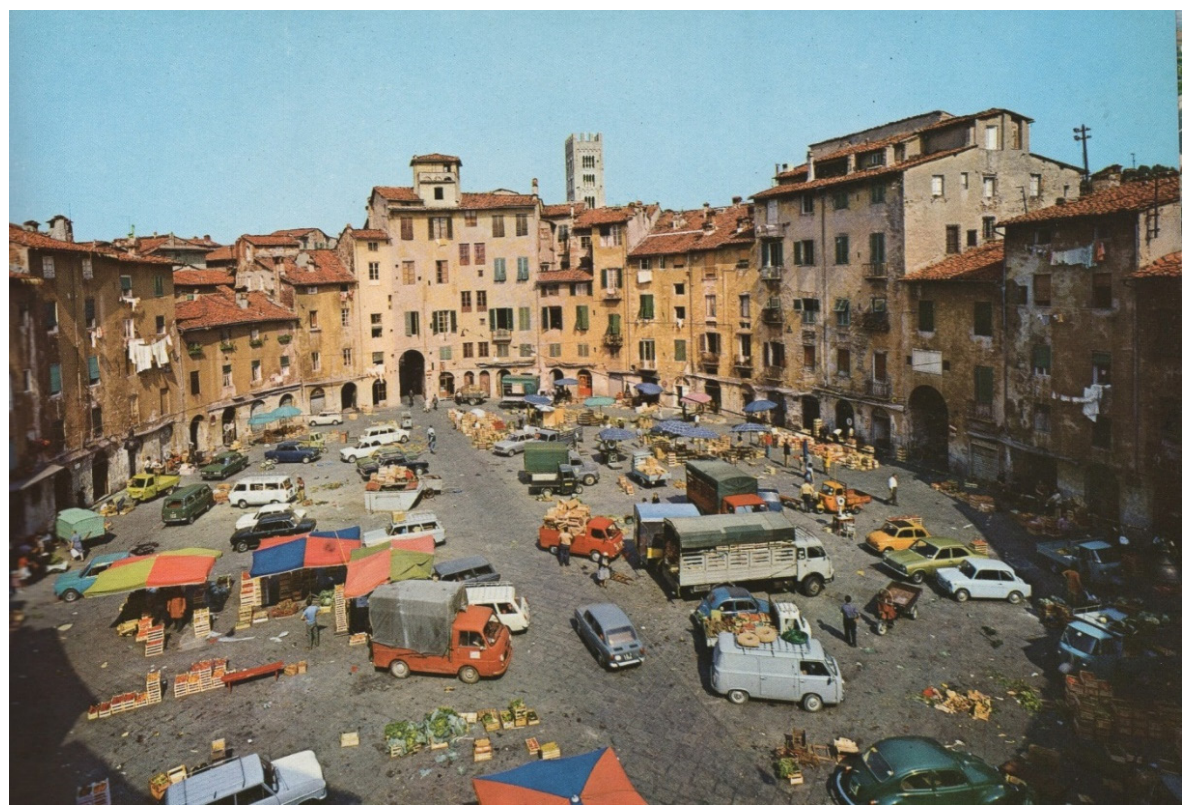

\subsection{Piazza Solferino (Solferino City Square) in Turin, Italy}

The area of the city square was located on the outskirts of $19^{\text {th }}$-century Turin. It marked a part of the southern border of the former Roman city. The look of the present Piazza Solferino (Fig. 32) has its source in the Carlo Promis project (1853) (Rossotti, 1995: 590-594; Lumbroso, 1877: 19). The creation of the city square was possible thanks to the decision to demilitarise the Citadel area (Devoti, 2016: 120).

10 Quotation translated by M. Woźniczka. 
The final shape of the space was included in the project Expansion of the city of Turin towards the former Citadel. It was signed by the chief engineer of Turin Edoardo Pecco (1857) (Devoti, 2016: 121).

The contemporary form of the city square (Fig. 33) is formed of four ellipses connected by an axis. The original plan - which was eventually abandoned assumed the city square to be surrounded by buildings with porticoes on the ground floors (Devoti, 2016: 121). The composition was completed by trees and central flower beds introduced after 1870. In 1877, in the centre of the city square on its longitudinal axis, the equestrian statue of Ferdinando di Savoia duca di Genova (designed by Alfonso Balzico) was erected.

In 1884, a monument to Giuseppe La Farina (designed by Michele Auteri-Pomar (Lanzardo, Poli, 2012: 125)) was placed in the space of the northern ellipse. In 1930, an allegorical fountain symbolising the four seasons (designed by Giovanni Riva (Società degli ingegneri e degli architetti in Torino, 1984: 88)) was built in the southern part of the city square. It created a fourth ellipse on the existing axis of the city square. The words of the Turin professor, "The way Promis chose to link the ancient city centre with the residential expansion area on [this] city square is a paradigmatic model of deconstruction open to an equally complete functional and physical restructuring" (Scarzella, Caldera, 1995 296-315, after: Devoti, 122), confirm the innovative nature of the Promis idea. The buildings surrounding the city square create a closed ("concrete") space with the features of a rectangle that measures $290 \times 40 \mathrm{~m}$. Openings occupy $22 \%$ of the perimeter, the two largest being on its shorter sides.

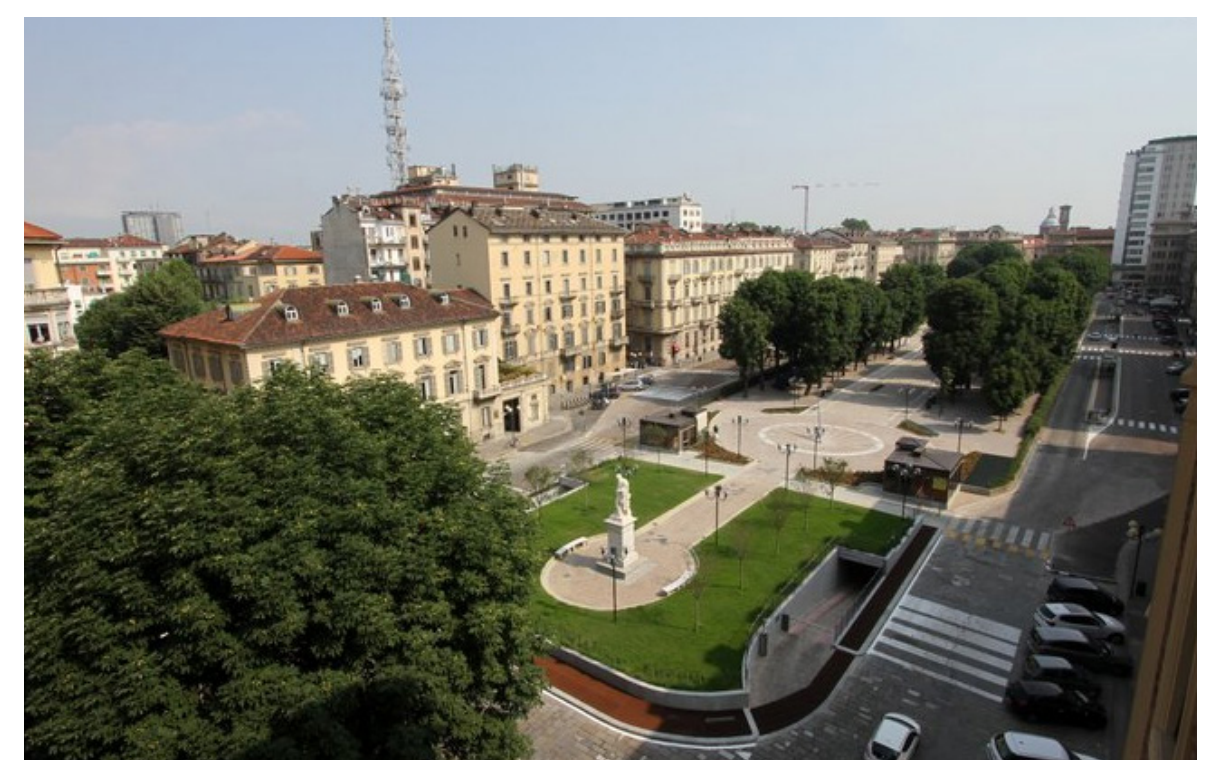

\subsection{Piazza Cesare Beccaria (originally Piazza Alla Croce) in Florence, Italy}

The city square is in the place of the former fourth ring of Florence's medieval walls. The creation of Piazza Cesare Beccaria (Fig. 35) is the result of the $19^{\text {th }}$-century reconstruction of the city by Giuseppe Poggi (Insabato, Ghelli, 2007: 299; Unknown Author, 1822: 150). The decision to modernise the space was associated with granting the city the status of the capital of Italy, which Florence was in the years 1865 to 1871 . The works carried out by Poggi began in 1865. As a result, some of the walls surrounding the city were demolished. However, the city gates were not removed. The described city square was arranged next to one of the preserved gate which was called Porta alla Croce.

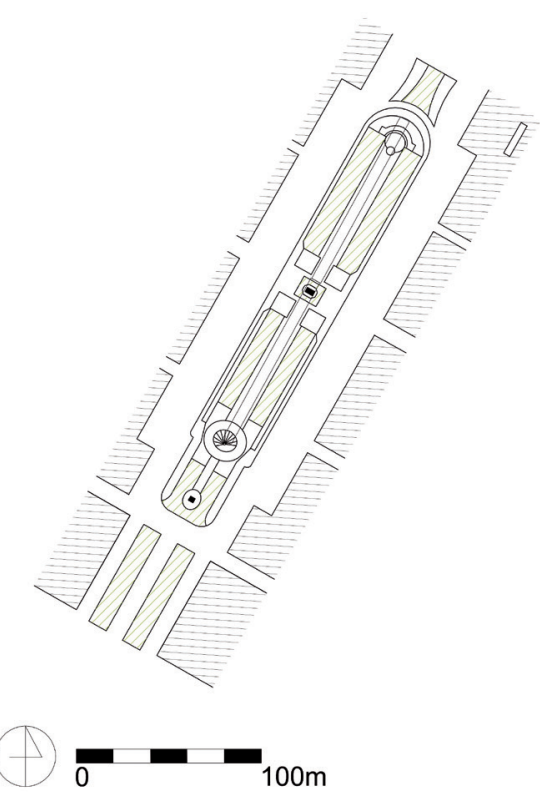

Fig. 32. Piazza Solferino in Turin - plan (drawing by M. Woźniczka)

Fig. 33. Piazza Solferino in Turin (source: http:// www.spaziotorino.it/scatto/?tag=meridiana, date of access: 2021/03/01) 


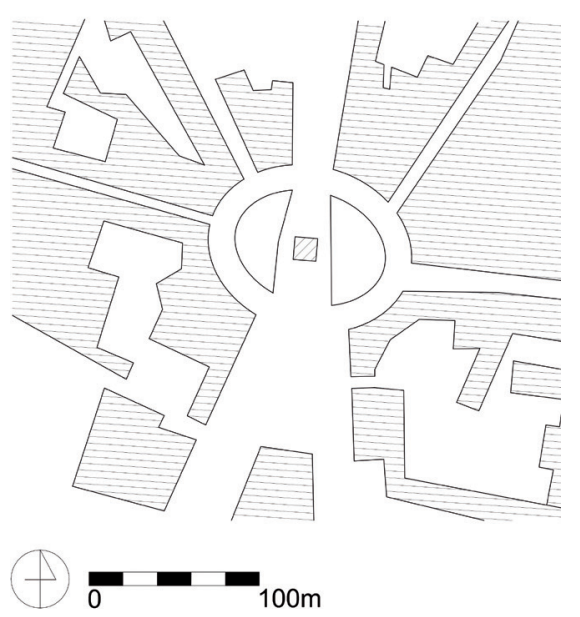

Fig. 34. Piazza Cesare Beccaria in Florence plan (drawing by M. Woźniczka)

Fig. 35. Nicola Sanesi $-19^{\text {th }}$-century figure of Piazza Beccaria and Zecca Vecchia (Poggi, 1946)

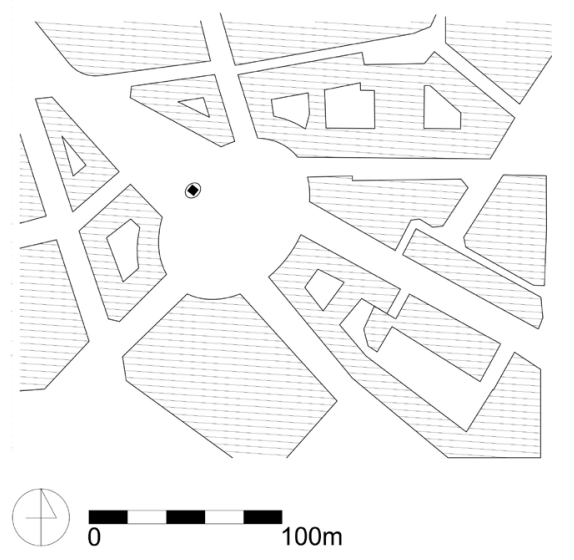

Fig. 36. Piazza Cordusio in Milan - plan (drawing by M. Woźniczka)
The city square has the shape of an ellipse measuring approximately 125 $x 85 \mathrm{~m}$ (Fig. 34). The centre of the ellipse is emphasised by the above-mentioned gate. The original name of the space, which was Piazza Alla Croce, was also derived from the gate. The city square is surrounded by Neoclassical tenement houses. Their concave elevations were adapted to the elliptical shape of the space.

The most important street leading to the city square is Viale Antonio Gramsci. The street enters the city square on the north side and then splits into two roads leading towards the municipal archives (built in 1989) and the Arno River. These roads also mark the triangular Piazza Giulio Prunai, which is the annex to Piazza Cesare Beccaria. The space stretching towards the Arno River was originally much larger, but it was developed in the $20^{\text {th }}$ century. $65 \%$ of the boundaries of Piazza Cesare Beccaria are formed by the walls of the buildings. As a result, it is a semi-closed ("objective") space.

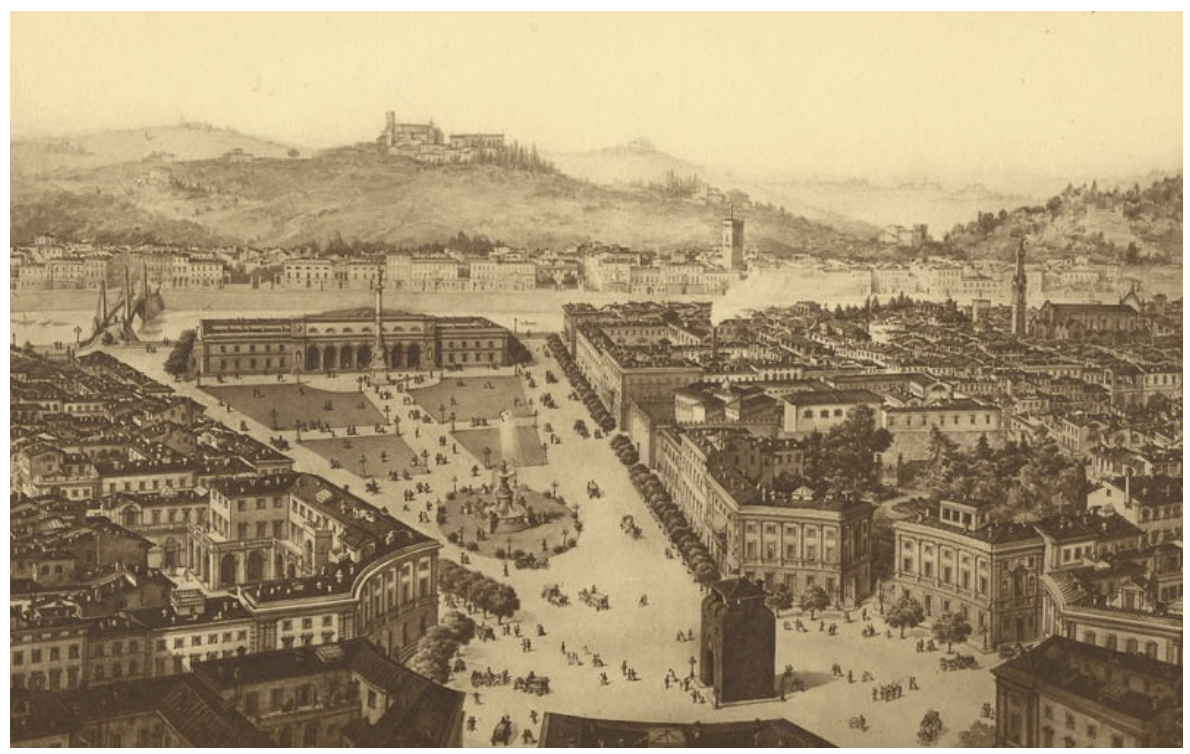

\subsection{Piazza Cordusio (Cordusio City Square) in Milan, Italy}

The city square is located inside a ring of Milan's walls from the Republic period. In the past, in the place of Piazza Cordusio (Fig. 36), there was the court of the Lombard dukes - Curia Ducis (Venosta, 1867: 52-54) from the sixth century. Historic buildings have been destroyed over the centuries. Their remains were demolished for the construction of nineteenth-century buildings. One of the few unchanged elements in the area was the nearby Piazza Mercanti. The Cathedral of the Birth of St. Mary in Milan is also located a short distance from Piazza Cordusio.

The present shape of Piazza Cordusio dates back to the turn of the nineteenth and twentieth centuries (Fig. 37). The foundation of the city square owes much to Cesare Beruto's plan (1884) (Burno, 2016: 216, 225). The project covered the most important streets of the Piazza Cordusio area.

The edges of Piazza Cordusio are formed by the edifices of buildings erected at the turn of the nineteenth and twentieth centuries. Some of these are: Palazzo Broggi (designed by Luigi Broggi, 1899-1901), Palazzo delle Assicurazioni Generali (designed by Luigi Tenenti, 1897-1899), Palazzo Biandrà (designed by Luca Beltrami, 1900), Palazzo del Credito Italiano (designed by Luigi Broggi, Cesare Nava, 1907-1912) (Maulsby, 2014: 68). Their façades are adapted to the line of ellipse. 
In 1899, the statue of Giuseppe Parini (designed by Luca Beltrami) was located on the shorter axis of the ellipse forming Piazza Cordusio. The monument with the building façades accounted for $53 \%$ of the city square's perimeter and emphasised its elliptical shape. As a result, the interior of the city square is semi-closed ("objective"). Its dimensions are approximately $63 \times 95 \mathrm{~m}$.

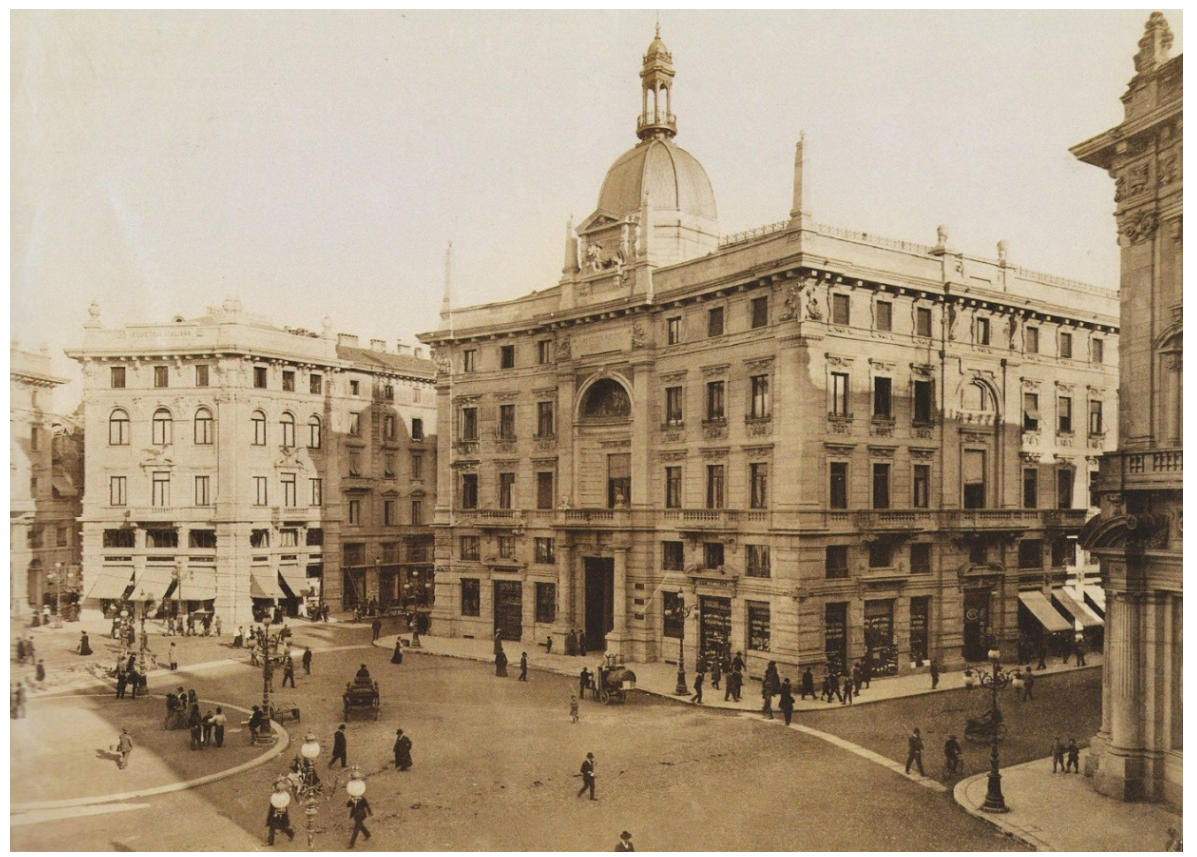

\subsection{Plaza Moyua (Moyua City Square) in Bilbao, Spain}

Plaza Moyua (Fig. 38) is located in the centre of Bilbao. It is also situated at the intersection of Bilbao's two most important arteries. The original public space, on the site of the later Plaza Moyua, was shaped in $1873^{11}$. Initially, this area was planted with trees. Inside the ellipse there was a statue of Viuda de Epalza (designed by Agustín de Querol, turn of the $19^{\text {th }} / 20^{\text {th }}$ century). What is rare is that the monument was not placed at the intersection of the axis of ellipse. It was removed from the city square in $1946^{12}$.

The most important buildings surrounding the city square were built at the end of the nineteenth century and the first half of the twentieth century. The examples of the buildings erected at that time are: El Palacio Chavarri (Paul Hankar, 1894) (Mas Serra, 2006), Hotel Carlton (Manuel Maria Smith, 192613), Edificio La Aurora (Manuel Galindez, 1934) (Susperregui Virto, 2000: 54-59; García, 2008) or Edificio de la Agencia Estatal de Administración Tributarua (Antoni Zobarán Manene, 1943).

Officially, the name of Mouya City Square was given in 1937. In the 1940s, due to the design of Jose Luis Salinas, the space gained a layout that is visible to this day. It is characterised by a central fountain and flower gardens forming an ellipse (Fig. 39). The façades of buildings surrounding Plaza Moyua form the shape of an ellipse. Its dimensions are approximately $115 \times 90 \mathrm{~m}$. In 1997, the second reconstruction of the city square was completed. The works were related to the construction of an underground line below the surface of the city square. However, the form of the city square
Fig. 37. Piazza Cordusio - in the centre is the Palazzo delle Assicurazioni Generali, 1902 (source: https://blog.urbanfile.org/2013/11/15/ zona-cordusio-la-creazione-del-cordusio/ piazza-cordusio-e-il-palazzo-dellegenerali-1902/, date of access: 2021/03/01)

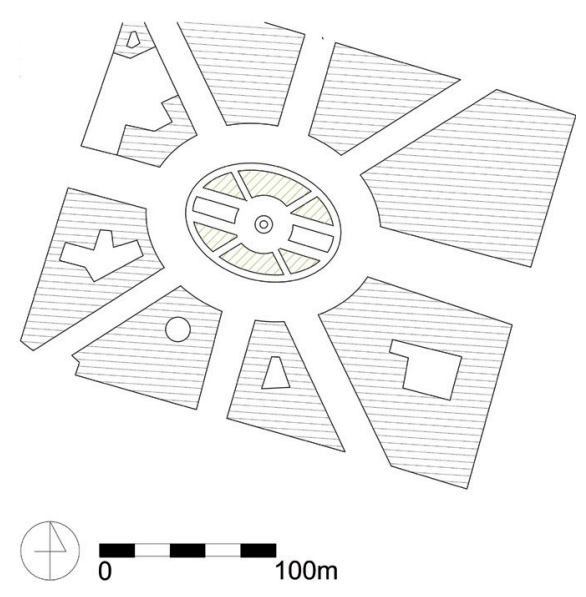

Fig. 38. Plaza Moyua in Bilbao - plan (drawing by M. Woźniczka)

\footnotetext{
11 See: http://www.bilbaopedia.info/plaza-moyua, after: González Oliver, J. Calles y rincones de Bilbao. Ayuntamiento de Bilbao, 2007 (date of access: 2021/03/01).

12 Ibidem.

13 https://www.hotelcarlton.es/nuestra-historia.html (date of access: 2021/03/01).
} 


\section{口:: technical EDtransactions}

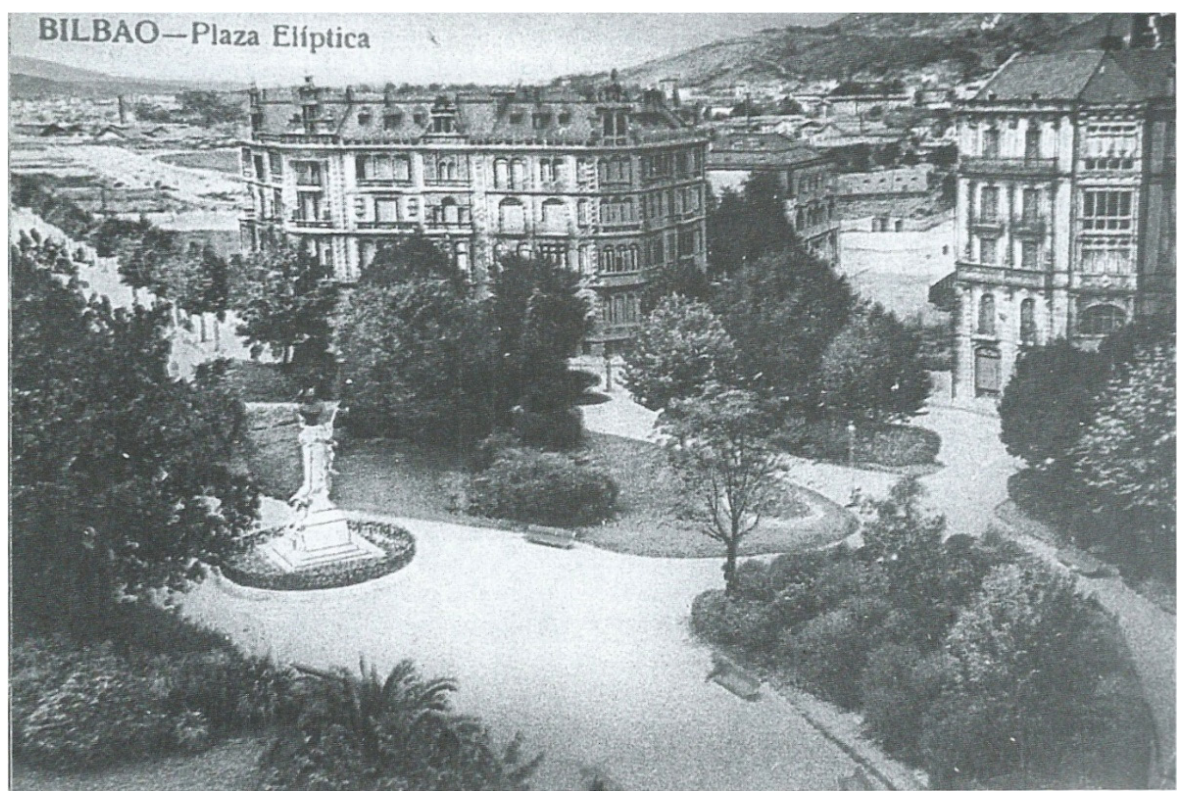

Fig. 39. Plaza Moyua in the first third of the twentieth century, source: Albistegui, A. A. (2000). Urbanismo en Bilbao: 1900-1930, (p. 120). Vitoria - Gasteiz: Servicio Central de Publicaciones del Gobierno Vasco [after] http://www.bilbaopedia.info/plazamoyua (date of access: 2021/03/01)
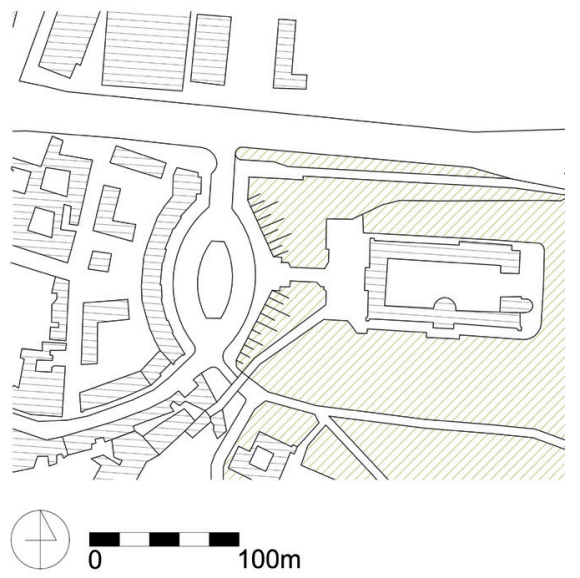

Fig. 40. Plac Zamkowy (Castle City Square) in Lublin - plan (drawing by M. Woźniczka)

Fig. 41. Plac Zamkowy (Castle City Square) in Lublin; photo by L. Demidowski, (source: https://www.biblioteka.teatrnn.pl/dlibra/ publication/135227/edition/129131/content, date of access: 2021/03/01) ("objective") space. has not changed, and its space is still semi-closed ("objective") with $38 \%$ of the perimeter occupied by openings.

\subsection{Plac Zamkowy (Castle City Square) in Lublin, Poland}

Castle City Square is a relatively new space (Fig. 40). Its creation was associated with the tenth anniversary of the establishment of the Polish Committee of National Liberation (Chmielewski, 2021; Zętar, 2019: 63-83; 2017: 6-7), celebrated in 1954 in Lublin. The works carried out at that time included: construction of the city square; closing the city square with a row of tenement houses on the west side; construction of stairs connecting the square and the castle; renovation of the castle façade. The city square was built on the site of the Podzamcze district, which was demolished in 1942-1943 (Jamiołkowska, Kurzątkowski, 1986: 283). The location of the city square coincided with the former Szeroka Street. That was the main place of trade in the Jewish part of Lublin (Kuwatek, 2001: 104-105). The erected buildings have a historicising form (referring to the Baroque style) and three- or five-axis façades (Fig. 41). The ellipse measures approximately $110 \times 68 \mathrm{~m}$. The edge of the city square is marked by the buildings only on its west side. The façades of the buildings enclosing the city square constitute $49 \%$ of its perimeter.

From the east, the border of the interior is marked by the 'wall' of the hill. As a consequence of the shape of the surroundings, the interior is a semi-open

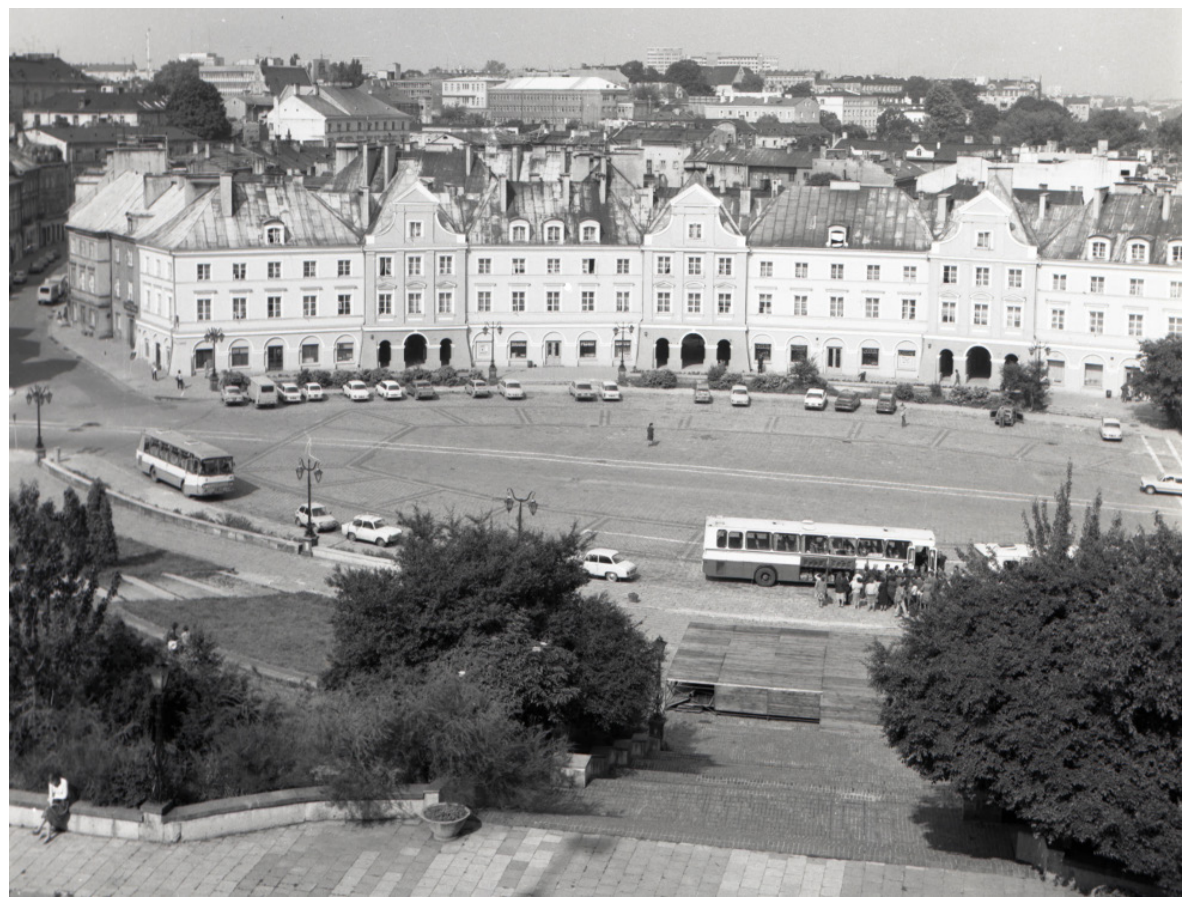




\subsection{Sergels Torg (Sergel City Square) in Stockholm, Sweden}

The origins of Sergel City Square (Fig. 42) date back to the interwar period. At that time, it was decided to rebuild the centre of Stockholm. Ultimately, the plan was implemented in 1960 (Hall, 1999: 181-186). One of the team members developing the project was architect David Helldén. The shape of the city square was consulted with Piet Hein - a Danish mathematician and inventor.

The city square is arranged on a hexagonal plan. Its space, consisting of two levels, is comprised of: a main square located below the road level; a second square on the north side; a traffic system in the form of a roundabout; a 'superellipse' (which is inside of the roundabout). The last of these elements is the reason why the described city square has become recognisable.

The 'superellipse' shape of the city square was introduced into the interior and named 'superellipse' by Piet Hein. He defined the superellipse in the following way: "The superellipse has the same convincing unity as the circle and ellipse, but it is less obvious and less banal" (Gardner, 1989: 244) ${ }^{14}$. The surface of the ellipse - measuring approximately $45 \times 40$ metres, contains dozens of fountains (Fig. 43). In 1972, its centre was additionally emphasised by a sculpture called

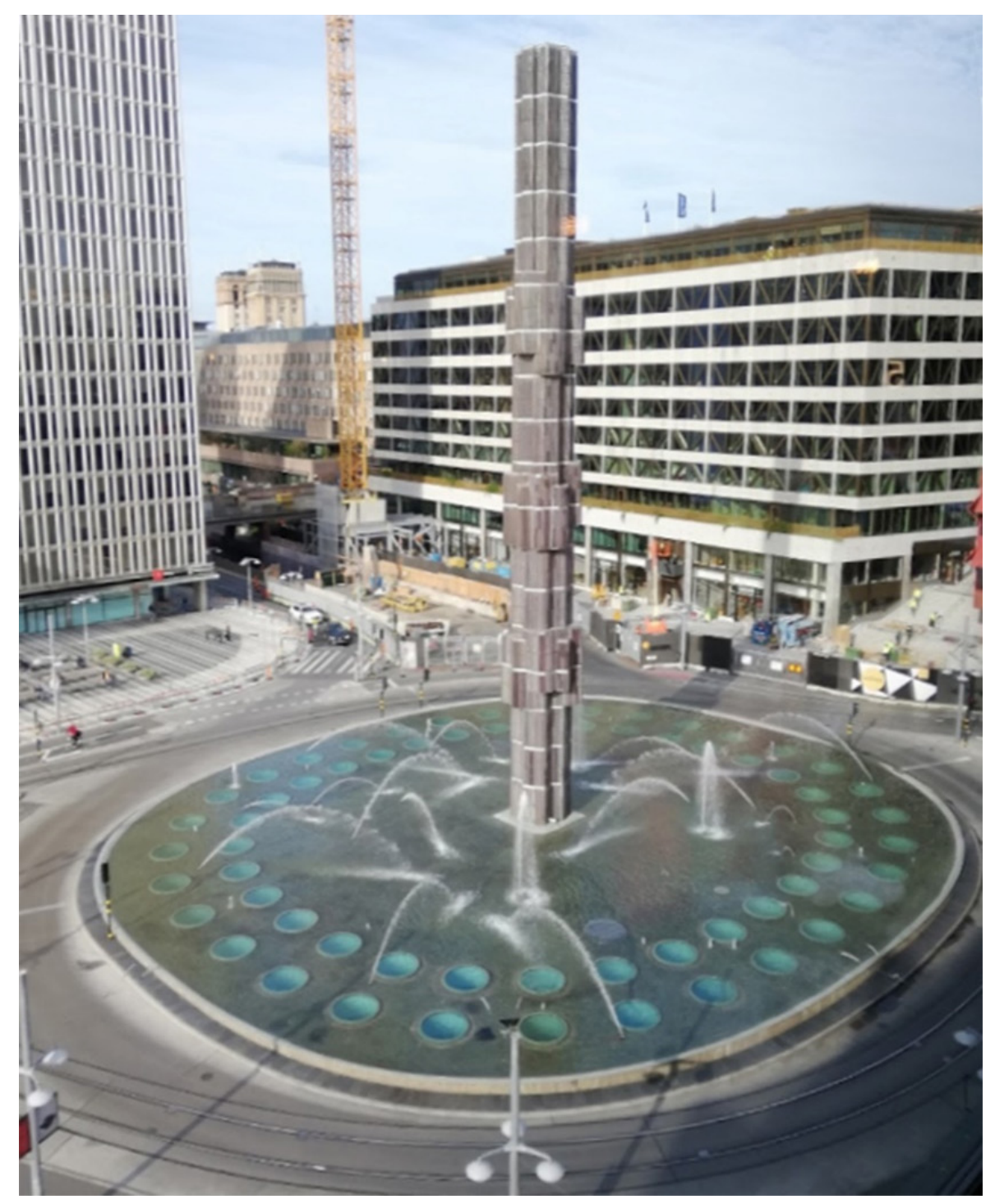

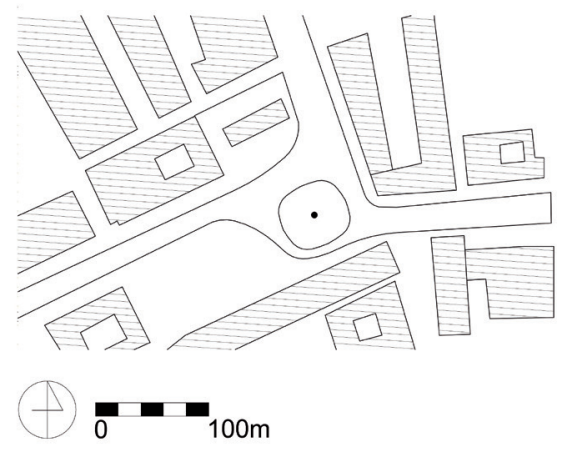

Fig. 42. Sergels Torg in Stockholm - plan (drawing by M. Woźniczka)
Fig. 43. Sergels Torg in Stockholm; photo by B. Gundersen (source: https://goo.gl/ maps/btTxVBBDLVXbUVG69, date of access: 2021/03/01) 14 A superelipse is a shape described by Gabriel Lamé in the $19^{\text {th }}$ century with the formula $\left|\frac{x}{a}\right|^{n}+\left|\frac{y}{b}\right|^{n}=1$.
The name 'superellipse' was given by Piet Hein in the $20^{\text {th }}$ century. 


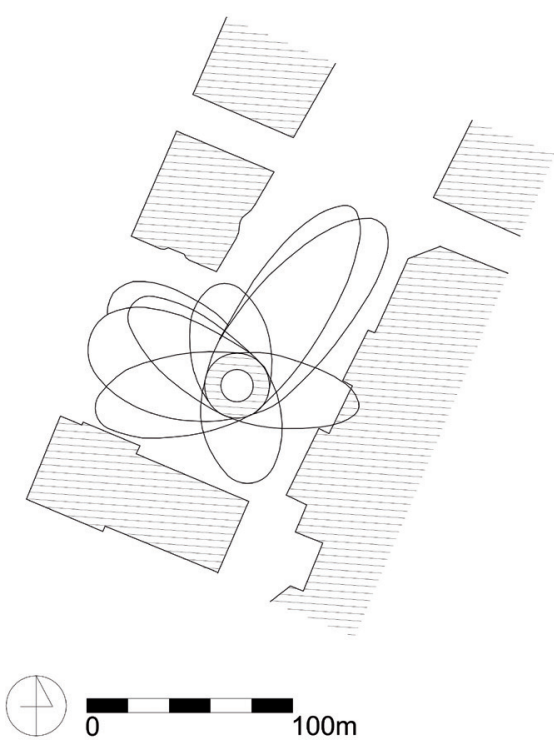

Fig. 44. Public square Hudson Yard in New York - plan (drawing by M. Woźniczka)

Fig. 45. Detail of the ellipse in the floor plane (source: https://www.nbwla.com/projects/ park/public-square-and-gardens-hudsonyards, date of access: 2021/03/01)
"Crystal Vertical Accent" (designed by Edvin Öhrström). As a result, the Sergel City Square can be treated both as closed ("concrete") interior and semi-closed ("subjective") interior (29\% of openings). The space of the city square is not in the shape of an ellipse, but the inner superellipse is its most important area.

\subsection{Public square Hudson Yard in New York, USA}

The city square (Fig. 44) is located in the west of Manhattan. The project was designed by Nelson Byrd Woltz Landscape Architects (2019). The created space is surrounded by modern skyscrapers, whose arrangement does not follow the shape of an ellipse. The shape of an ellipse is revealed only in the system of pedestrian paths and greenery arranged in accordance with the course of nine ellipses (Fig. 45). The largest of these measures approximately $120 \times 45 \mathrm{~m}$. The central, tenth ellipse is the most important point in space, created as a monumental sculpture. It is also a lookout tower. The city square - $65 \%$ of which is marked by the façades of skyscrapers - is a semi-closed ("objective") space but is not perceived as an ellipse.

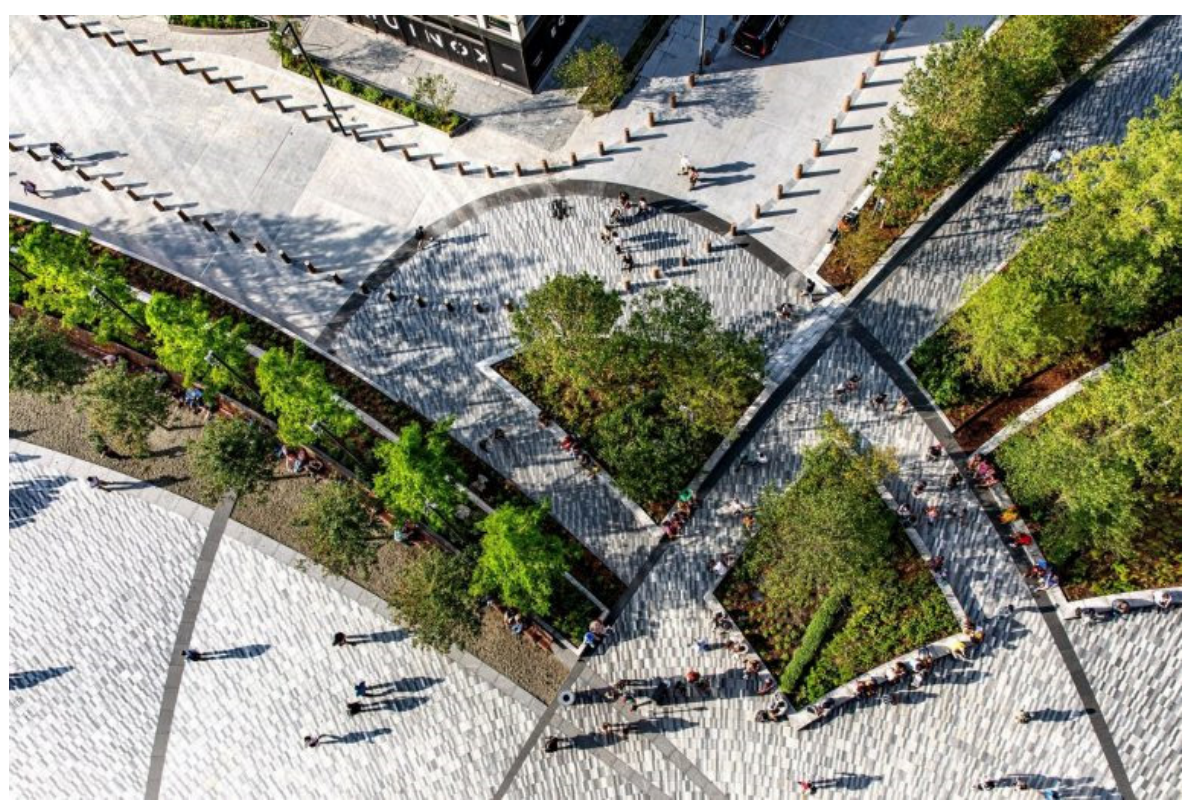

\subsection{Initial attempt to classify elliptical city squares}

The presented examples show three basic types of elliptical city squares:

- The first group consists of closed ("concrete") interiors, surrounded by dense buildings adapted to the form of an ellipse.

- The second group consists of semi-closed ("objective") city squares, the space of which is not completely surrounded by buildings. Nevertheless, in their space, the edge of the ellipse is clearly marked.

- The third group consists of semi-open ("subjective") interiors, the edge of which is only fragmentary. This partially obliterates the readability of the ellipse.

There are also two types of interiors on the border of the above-mentioned groups:

- The first are closed, non-elliptical interiors, in which the ellipse is accentuated only in the plane of the floor.

- The second is places like Prato Della Valle in Padua. The city square is not surrounded by elliptical buildings. However, by introducing sculptures emphasising the shape of the ellipse, it is visible not only in the horizontal plane. 
The presented examples show how the shape of the ellipse can be used to create a public space in various ways and on different scales. In the past, the studied form was most often introduced as part of the reconstruction of historical buildings. Only in a few cases, including Lucca, was reference made to the earlier, elliptical land development. In twentieth-and twenty-first-century designs, there is a tendency to treat the ellipse in a new way. Its form can be multiplied, as in the New York example, or transformed into a 'superellipse'.

\subsection{Elliptical space in the Kurdwanów estate in Krakow, Poland}

The twentieth-century example of an ellipse that create public space is also part of the Kurdwanów estate in southern Krakow. The estate (project manager Anna Sierostawska) was erected in the 1980s in the former village of Kurdwanów. The complex of buildings was intended for 13,000 inhabitants. The investment area, almost devoid of any previous development, was situated on a gentle slope with a southern exposure.

Public space inspired by the shape of an ellipse was created in the second stage of the construction of the estate (Fig. 46). This zone is the first eye-catching element in the estate's plan. It owes this to its elliptical shape and dimensions, which are approximately $340 \times 130 \mathrm{~m}$. Apart from multi-family buildings, the project also included public services. Some of them - the kindergarten and the nursery - were placed in the core of the discussed ellipse. The mentioned public services are surrounded by greenery.

During the construction of the estate, the idea of the ellipse, the type of functions inside it and the central pedestrian route were preserved. In the western part of the ellipse, a primary school with adjacent playing fields was located (Fig. 47). In the eastern part there are tennis courts, a fitness club, an indoor swimming pool and a green area. The view opening towards the south was closed in 2010. A multi-family building was built in its place. The elliptical public space in the Kurdwanów estate is a semi-closed ("objective") interior. Free spaces between buildings - which are openings - constitute $42 \%$ of the perimeter of the ellipse. Nevertheless, its elliptical shape is difficult to see from ground level. This is due to the large size of the foundation and the distances between individual buildings forming the edge of the ellipse (Fig. 48).

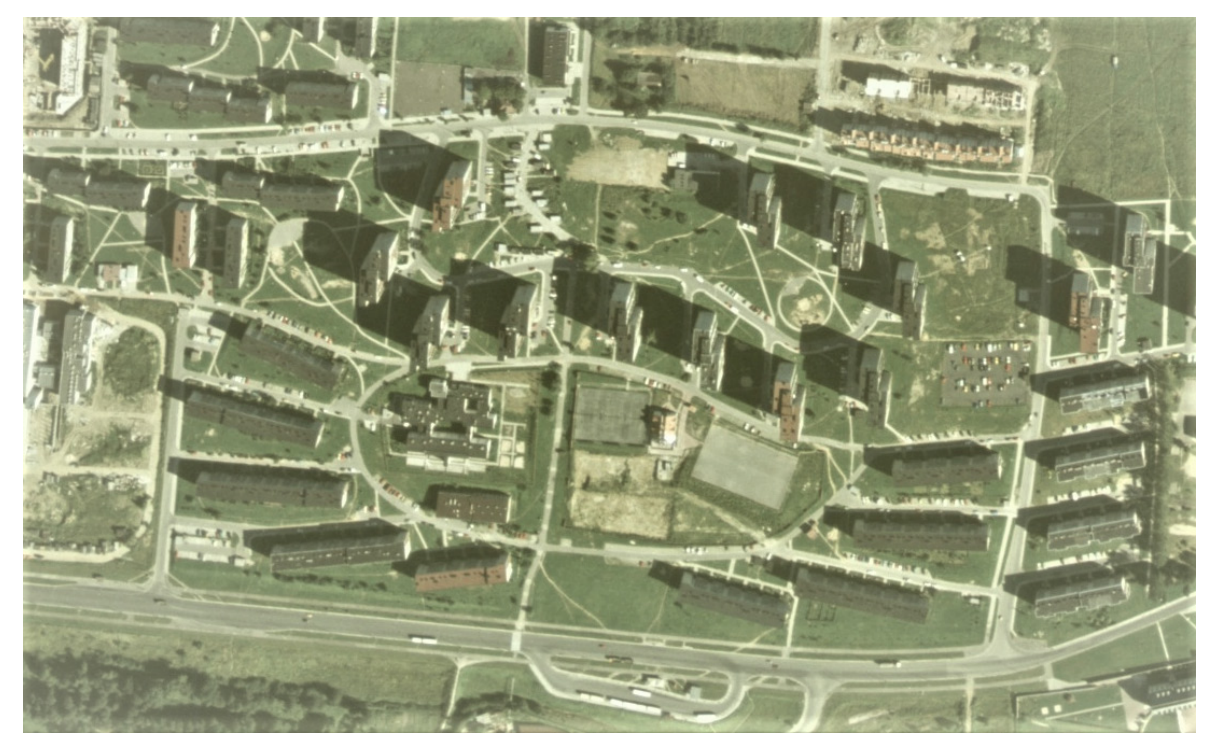

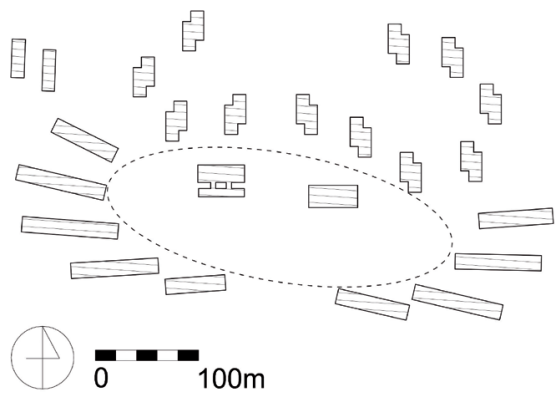

Fig. 46. Elliptical space in the Kurdwanów estate in Krakow (design) - plan (drawing by M. Woźniczka)

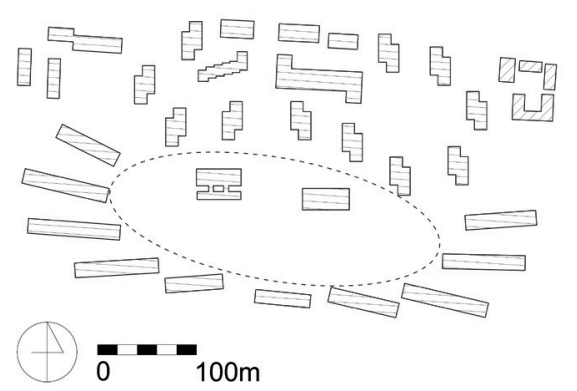

Fig. 47. Elliptical space in the Kurdwanów estate in Krakow (nowadays) - plan (drawing by M. Woźniczka)
Fig. 48. Elliptical space in the Kurdwanów estate in Krakow, 1995 (source: Urząd Miasta Krakowa) 


\subsection{Conclusions concerning the city squares of elliptical plan}

The shape of an ellipse is often used as a solution to combine the functions of a city square and a transport network.

Monuments and other accentuation elements may be located at the intersection of the axis of the streets leading to the city square (e.g. Piazza Cesare Beccaria) or around its perimeter (e.g. Piazza Cordusio).

The ellipse was often introduced during the reconstruction of previously developed areas. This is due to the ease of adjusting its form to the existing urban fabric.

The ellipse is a form that combines the features of the interior on the plan of a circle and a rectangle. In its space, as in circular systems, new streets are easily introduced. In elliptical interiors, as in rectangular interiors, it is easy to adjust the façades of buildings to the edges of the city square. This is due to the smaller arc of curvature than in the case of the circle.

In a few implementations the ellipse was introduced into previously undeveloped spaces (e.g. Kurdwanów).

Small and medium-sized interiors are the optimal size of the city square ellipse. In them, the shape of the ellipse is clearly visible. In extensive projects, the shape of the ellipse is blurred. This is despite the comparable degree of space enclosure with buildings (e.g. Kurdwanów).

In most cases, the most important objects are located on the shorter axis of the ellipse. This rule does not apply to entrances to the city square.

Elliptical spaces are more dynamic than those on a circular or rectangular projection.

Interiors on an ellipse plan are sometimes enlarged by annexes directly adjacent to the elliptical city squares (e.g. Piazza Cesare Beccaria).

\subsection{The final, comparative conclusions}

The form of octagonal city squares is generally more static, the form of elliptical city squares is usually more dynamic.

Octagonal city squares are less susceptible to variations and variants than elliptical city squares.

Considering the elliptical city squares, one may note more use of the author's creative freedom than in case of octagonal city squares.

A compositional accent such as a single statue tends to be placed exclusively in the centre of the octagonal city square, whereas the number and distribution of such accents enjoys substantial freedom of choice in elliptical city squares.

Elliptical city squares are more often designed and built than octagonal city squares, especially when the circulation or traffic is taken into account.

Until the nineteenth century, octagonal city squares were more often designed and built than elliptical city squares.

Both discussed Krakow examples stand out for the exceptionally original adaptation and transformation of the motif of an octagon or an ellipse. 
1.

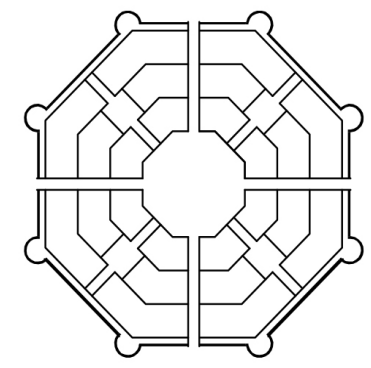

4.

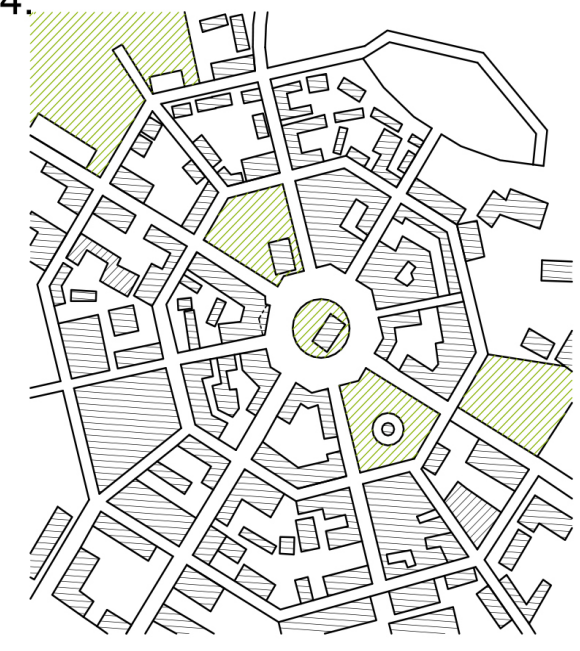

2.

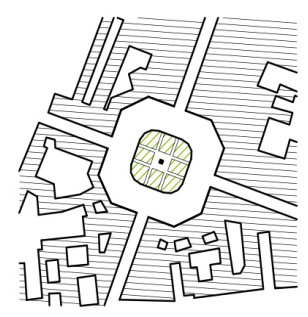

3.

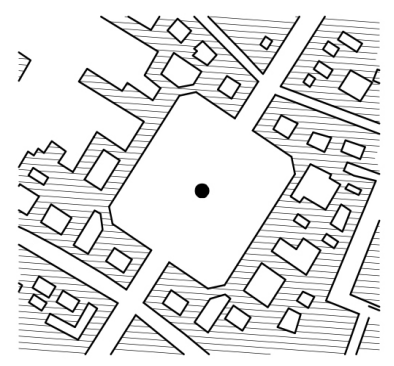

5.

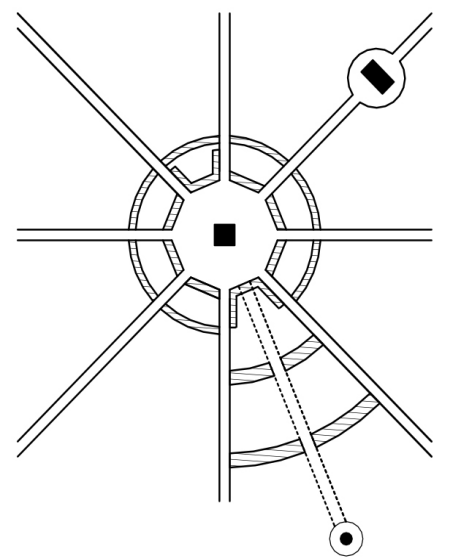

8.
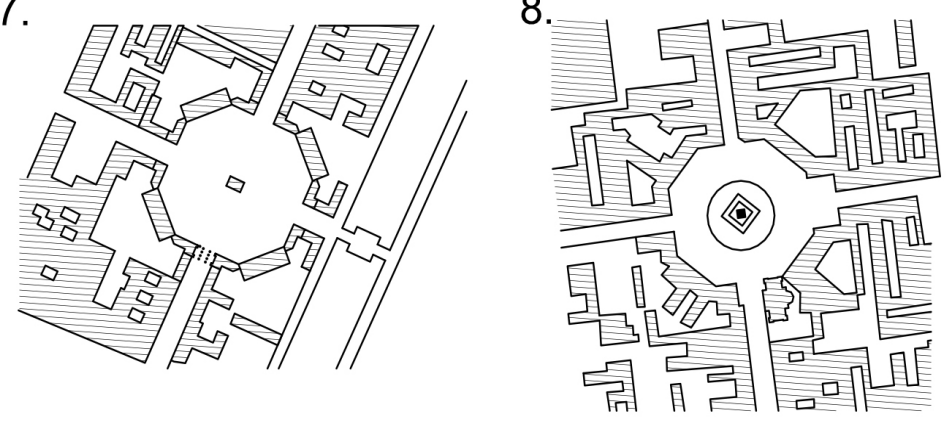

9.

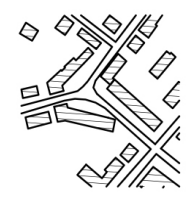

10.

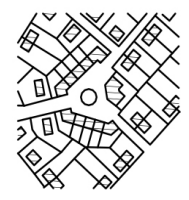

Fig. 49. Octagonal city squares: 1. Martini's project, 2. Place Hoche, 3. Place Vendôme, 4. Raatihuoneentori, 5. Square in Pokój, 6. Place Stanislas, 7. Amalienborg, 8. plac Wolności, 9. The Urzędnicze Estate square (nowadays), 10. The Urzędnicze Estate square (design) (drawings by M. Woźniczka) 


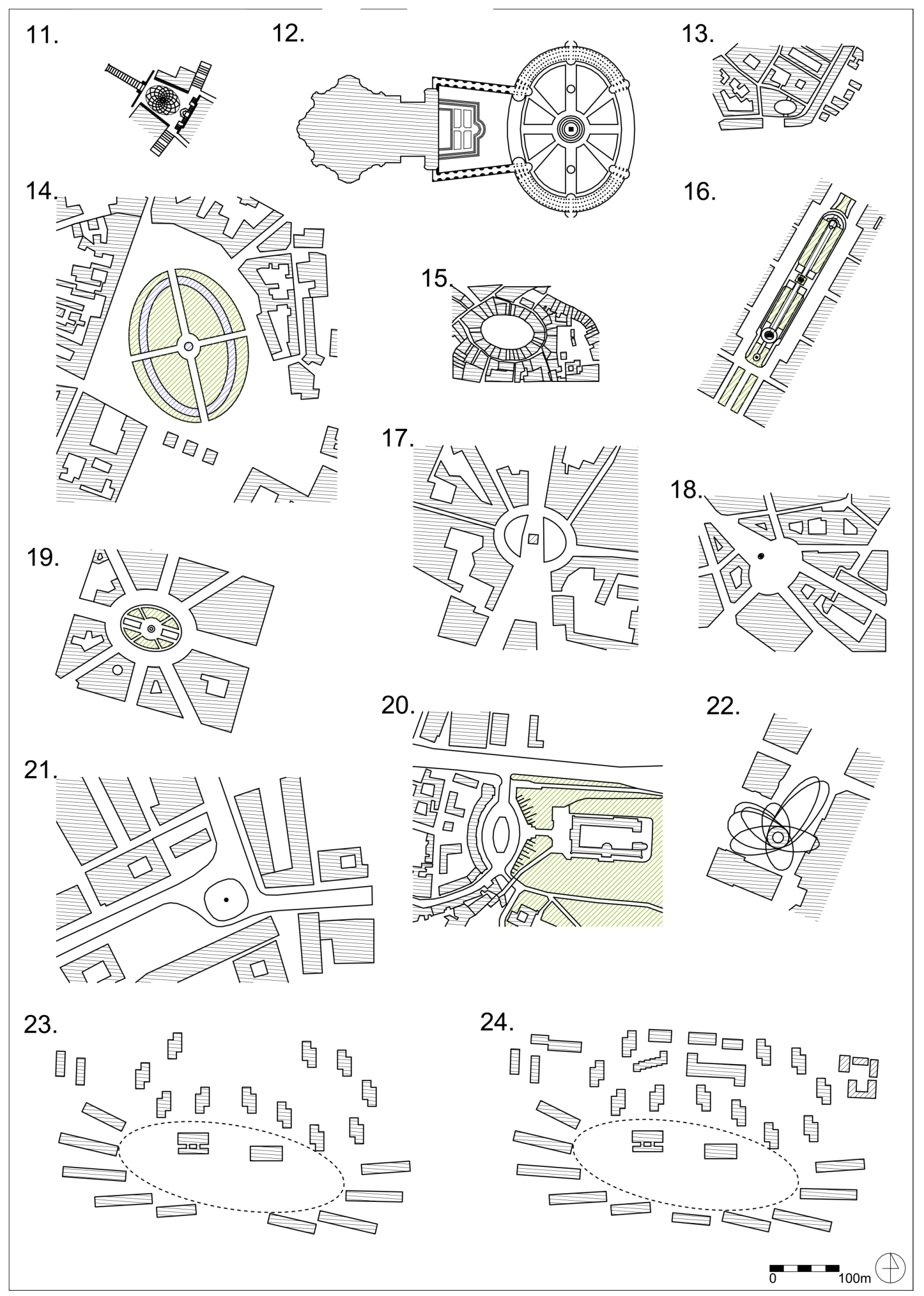

Fig. 50. Elliptical city squares: 11. Piazza del Campidoglio, 12. Piazza San Pietro, 13. Piazza Nuova, 14. Prato Della Valle, 15. Piazza Dell'Anfiteatro, 16. Piazza Solferino, 17. Piazza Beccaria, 18. Piazza Cordusio, 19. Plaza Moyua, 20. plac Zamkowy, 21. Sergels Torg, 22. Hudson Yard, 23. Elliptical space in the Kurdwanów estate (design), 24. Elliptical space in the Kurdwanów estate (nowadays) (drawings by M. Woźniczka) 


\section{References}

\section{Octagonal squares}

Bogdanowski, J. (1976). Kompozycja i planowanie w architekturze krajobrazu. Wroctaw: Wydawnictwo PAN.

Grimal, P. (1970). Miasta rzymskie. Warszawa: Wydawnictwo PWN.

Gutkind, E.A. (1965). International History of City Development. Vol. II: Urban Development in the Alpine and Scandinavian countries. New York: The Free Press.

Gutkind, E.A. (1970). International History of City Development. Vol. V: Urban Development in the Western Europe: France and Belgium. New York: The Free Press.

Johnston, N.J. (1983). Cities in the Round. Seattle \& London: University of Washington Press.

Königer, E. (1938). Kunst in Oberschlesien. Breslau: Verlag Priebatsch Buchandlung.

Kostof, S. (1991). The City Shaped. Urban Patterns and Meanings Through History. London: Thames and Hudson.

Koter, M. (1984). Rozwój uktadu miejskiego Łodzi wczesnoprzemystowej. In: J. Szewczyk (Ed.), Miscellanea tódzkie. Vol. 1: Myśl urbanistyczna a rozwój przestrzenny Łodzi. Łódź: Muzeum Historii Miasta Łódź.

Martimort, A.G. (1987). The Church at Prayer. Vol. I: Principles of the Liturgy. Collegeville: Liturgical Press.

Motak, M. (2020). Osiedle Urzędnicze w Krakowie. Urbanistyka i architektura 1924-1942. Kraków: Wydawnictwo Politechniki Krakowskiej.

Münter, G. (1957). Idealstädte. IhreGeschuchte von 15.-17. Jahrhundert. Berlin: Henschelverlag.

Olenderek, J. (2011). tódzki modernizm $i$ inne nurty przedwojennego budownictwa. Łódź: Dom Wydawniczy Księży Młyn.

Ostrowski, W. (1996). Wprowadzenie do historii budowy miast. Ludzie i środowisko. Warszawa: Oficyna Wydawnicza Politechniki Warszawskiej.

Piprek, M. (1988). Architektura Finlandii. Warszawa: Arkady.

Radwański, D. (2018). Plan owalny w architekturze. Gliwice: Wydawnictwo Politechniki Śląskiej.

Ruler, D.A. van (1984). Krzyż i koło: dusza świata. Architektura, 420, 22-25.

Szafer, T.P. (1955). Ze studiów nad planowaniem miast w Polsce XVIII i pocz. XIX w. In: Studia z historii budowy miast (pp. 47-81). Warszawa: Instytut Urbanistyki i Architektury.

Trachtenberg, M., Hyman, I. (2002), Architecture from Prehistory to Postmodernity. New York: Harry N. Abrams.

Webb, M. (1990). The City Square. A Historical Evolution. New York: Whitney Library of Design.

Witruwiusz. (1999). O architekturze ksiagg dziesięć. Warszawa: Prószyński i S-ka.

Zarębska, T. (1971). Teoria urbanistyki włoskiej XV i XVI wieku. Warszawa: Państwowe Wydawnictwo Naukowe.

Zucker, P. (1959). Town and Square from the Agora to the Village Green. New York: Columbia University Press.

\section{Elliptical squares}

Burno, F. (2016). Spektakl i modernizacja Miasta wtoskie w okresie faszyzmu 1922-1945. Warszawa: Fundacja Kultura Miejsca, Akademia Sztuk Pięknych w Warszawie.

Cervelatti, P.L. (1991). Emilia Romagna. La cultura delle città. Vol. 3. Firenze: Cantini.

Chmielewski, J. (2021). Wyburzanie dzielnicy żydowskiej na Podzamczu. Retrieved from http://teatrnn.pl/leksykon/artykuly/wyburzanie-dzielnicyzydowskiej-na-podzamczu/ (date of access: 2021/01/05). 
Comune di Bagnacavallo. (n.d.). http://www.comune.bagnacavallo.ra.it/content/ download/1733/22602/file/strumentiurbanistici.pdf (date of access: 2021/03/01).

Devoti, Ch. (2016). La sede di rappresentanza delle Generali a Torino nei piani urbanistici per la città. In: C. Benocci (Eds.), Le assicurazioni Generali nelle citta italane-tra la fine dell'ottocento e Gui inizi del novocento (pp. 117-128). Roma: Edizioni Kappa.

Donati, R. (1978). Tuscany. Narni-Terni: Plurugraf.

Futugawa, Y., Mendini, A. (1993). Arata Isozaki \& Associates Tsukuba Center Building, Ibaraki, Japan, 1979-83. Tokio: A.D.A Edita.

García, J. (2008). Una inmobiliaria compra por 30 millones un edificio de Axa junto a la Plaza Moyua. El Correo. Retrieved from https://www. elcorreo.com/vizcaya/20080117/vizcaya/inmobiliaria-compra-millonesedificio-20080117.html?ref=https:\%2F\%2Fes.wikipedia.org\%2F (date of access: 2021/03/01).

Gardner, M. (1989). Mathematical carnival. Washington: The Mathematical Association of America.

Goethe, J.W. (1885). Goethe's travels in Italy. London.

Gómez, E.M., Moral-Andrés, F. (2017). Controlled Landscapes or Building Sustainability in Public Spaces. Case of Studies of Padova and Moscow. In: R.A. Fernandez, S. Zubelzu, R. Martinez (Eds.), Carbon Footprint and the Industrial Life Cycle (pp. 85-106). New York: Springer.

Hall, T. (1999). Huvudstad i omvandling - Stockholms planering och utbyggnad under 700 år. Stockholm: Sveriges Radio.

Ingarden, K. (2020). Arata Isoaki - a Sfinx, an Oedipusor the ever-changing Kamo No Chōmeiof our times? In: W. Kosiński (Eds.), Teka Komisji Urbanistyki i Architektury (pp. 120-133). Vol. XLVIII. Kraków: Oddział PAN w Krakowie.

Insabato, E., Ghelli, C. (Eds.). (2007). Guida agli archivi di architetti e ingegneri del Novecento in Toscana. Firenze: Edifir.

Jamiołkowska, J., Kurzątkowski, M. (1986). Lublin. In: W. Kalinowski (Eds.), Zabytki urbanistyki $i$ architektury w Polsce. T. 1: Miasta historyczne (pp. 277-304). Warszawa: Arkady.

Kuwatek, R. (2001). Lublin. Jerozolima Królestwa Polskiego. Lublin: Stowarzyszenie „Dialog i Wspótpraca”.

Lanzardo, D., Poli, F. (2012). Torino la città delle statue. Fantasmi di pietra sulla scena urbana. Torino: Edizioni del Capricorno.

Lumbroso, G. (Ed.). (1877). Memorie e lettere di Carlo Promis. Architetto, Storico Ed Archeologo Torinese (1808-1873). Torino: Fratelli Bocca.

Malpeli, M.L. (1806). Dissertazioni sulla storia antica di Bagnacavallo. Faenza: Michele Gaspare Conti.

Mas Serra, E. (2006). El Palacio Chávarri. Retrieved from http://www.bilbao.eus/ castella/residentes/vivebilbao/publicaciones/periodicobilbao/200608/ pag16.pdf (date of access: 2021/03/01).

Maulsby, L.M. (2014). Fascism, Architecture, and the Claiming of Modern Milan 1922-1943. Toronto: University of Toronto Press.

Mazzarosa, A. (1843). Guida di Lucca e dei luoghi più importanti del ducato. Lucca: Giuseppe Giusti.

Mezer, A. (2010). The Elllypse, The Historical and Mathematical Journey. Hoboken: Wiley.

Moszyński A. (1970). Dziennik podróży do Francji i Wtoch. Kraków: Wydawnictwo Literackie.

Pasquali, S. (2009). MEMMO, Andrea. Dizionario biografico degli italiani, 73. Retrieved from https://www.treccani.it/enciclopedia/andrea-memmo_ (Dizionario-Biografico)/ (date of access: 2021/03/01).

Poggi, L. (1946). L'architetto Giuseppe Poggi e il suo archivio, conferenza letta il 31 maggio 1946 alla Società Leonardo da Vinci, special edition "La Nuova Città". Retrieved from https://www.guidemeflorence.com/pl/2020/11/03/ rampy-poggi-florencja/ (date of access: 2021/03/01). 
Società degli ingegneri e degli architetti in Torino. (1984). Beniculturali ambientali Nel Comune del Torino. Torino: Politecnico di Torino. Dipartimento Casa Città.

Puppi, L., Toffanin, G. (1983). Guida di Padova. Arte e storiatra vie e pizze. Trieste: Lint.

Rossotti, R. (1995). Le Strade di Torino. Roma: Newton Compton.

Scarzella, P., Caldera, C. (1995). Il complessonodale di piazza Solferino e corso Re Umberto. In: Politecnico di Torino, Dipartimento di ingegneria dei sistemi edilizi e territoriali, Torino nell'Ottocento e nel Novecento: ampliamenti e trasformazioni entro la cerchia dei corsi napoleonici, Torino: Celid.

Susperregui Virto, J.M. (2000). Manuel I. Galíndez 1892-1980. Vol. 6: Arquitectos contemporáneos. Pamplona: Colegio Oficial de Arquitectos Vasco-Navarro, Delegación en Vizcaya.

Tesori d'Italia. (1975). Milano: Reader's Digest.

Unknown Author. (1822). Porta alla Croce. Guida della città di Firenze. Ornata di pinata e vedut. Firenze: Antonio Campani.

Venosta, F. (1867). Milano e le sue vie. Studi storici. Vol. 1. Milano: Giocondo Messaggi.

Woltz, N.B. (n.d.). Landscape Architects. Retrieved from https://www.nbwla. $\mathrm{com} /$ projects/park/public-square-and-gardens-hudson-yards (date of access: 2021/03/01).

Wróbel, T. (1971). Zarys historii budowy miast. Wroctaw: Zakład Narodowy imienia Ossolińskich.

Zaggia. S. (2010). «Isoletta sacra al commercio ed all'arti». Andrea Memmo, Melchiorre Cesarotti e il Prato della Valle come esperimento di riforma del paesaggiourbano. In: F. Finotti (Eds.), Melchiorre Cesarotti $e$ le trasformazioni del paesaggioeuropeo. Trieste: EUT Edizioni Università di Trieste. Retrieved from https://www.openstarts.units.it/ handle/10077/4458 (date of access: 2021/03/01).

Zava, S. (2018). Prato Della Valle. Padova: Il Poligrafo.

Zętar, J. (2017). Jak budowano plac Zamkowy... Gazeta Wyborcza. Magazyn Lubelski, 18 sierpnia, 6-7.

Zętar, J. (2016). Narracje (nie)pamięci: Plac Zamkowy. Topografia palimpsestu (cz. 2). Retrieved from https://blog.teatrnn.pl/laboratorium-nn/narracjeniepamieci-i-plac-zamkowy-topografia-palimpsestu-cz-2/ (date of access: 2021/03/01).

Zętar, J. (2019). Wielka Księga Miasta. Fotografie Lubelskiej Dzielnicy Żydowskiej w zbiorach ośrodka „Brama Grodzka - Teatr NN”. Folia Bibliologica, Vol. LXI, 63-83.

http://openlucca.it/ (date of access: 2021/03/01).

http://www.comune.torino.it/ (date of access: 2021/03/01).

https://www.barcelo.com(date of access: 2021/03/01).

https://piethein.com/superellipse/ (date of access: 2021/03/01).

https://vecchiamilano.wordpress.com/2011/09/22/cordusio/ (date of access: 2021/03/01).

http://www.bilbaopedia.info/plaza-moyua (date of access: 2021/03/01).

https://www.hotelcarlton.es/nuestra-historia.html (date of access: 2021/03/01). 


\section{Krótka historia formy ośmiokątnych i eliptycznych placów miejskich}

\section{Streszczenie}

Artykut rozpoczyna się krótką charakterystyką dwóch figur geometrycznych, tj. ośmioboku i elipsy, obejmującą ich genezę w architekturze i urbanistyce oraz przykłady budynków o planach opartych na tych figurach. Następnie omówione zostały wybrane place ośmioboczne i eliptyczne - ich geneza, kontekst, rozplanowanie, architektura je otaczająca, obiekty pojawiające się w ich obrębie oraz, w szczególności, kompozycja i forma urbanistyczna. Zastosowana zostata teoria wnętrz architektoniczno-krajobrazowych do wskazania typu danego wnętrza placowego ze względu na proporcję otwarć w ścianach placu. Omówiono 22 przykłady, w tym 10 placów ośmiobocznych i 12 eliptycznych, powstałych od XV do XX wieku. Ostatni przykład w każdej grupie, nietypowy i powstały w Krakowie w XX wieku, zostat omówiony bardziej szczegółowo. Wnioski przedstawiono osobno dla placów ośmiobocznych i eliptycznych, a następnie wspólnie dla obu grup w formie porównawczej.

Stowa kluczowe: elipsa, ośmiokąt, forma urbanistyczna, Kurdwanów, osiedle Urzędnicze 